\title{
Small round blue cell tumors of the sinonasal tract: a differential diagnosis approach
}

\author{
Lester DR Thompson \\ Department of Pathology, Woodland Hills Medical Center, Southern California Permanente Medical Group, \\ Woodland Hills, CA, USA
}

\begin{abstract}
One of the most challenging diagnostic categories within tumors of the sinonasal tract is the small round blue cell tumors. Biopsies are usually small and limited, resulting in considerable diagnostic difficulty for practicing surgical pathologists. These tumors share several overlapping histologic and immunophenotypic findings while also showing considerable variation within and between cases. Specific tumor site of origin, imaging findings, and clinical findings must be combined with the histology and pertinent ancillary studies if the correct diagnosis is to be reached. Discrimination between neoplasms is critical as there are significant differences in therapy and overall outcome. It is important to have a well developed differential diagnosis for this category of tumors, where each of the diagnoses is considered, evaluated, and either confirmed or excluded from further consideration. In an undifferentiated tumor, showing a small round blue cell morphology, using the mnemonic 'MR SLEEP' helps to highlight tumors to consider: melanoma, mesenchymal chondrosarcoma, rhabdomyosarcoma, sinonasal undifferentiated carcinoma, squamous cell carcinoma (including NUT carcinoma), small cell osteosarcoma, lymphoma, esthesioneuroblastoma (olfactory neuroblastoma), Ewing sarcoma/primitive neuroectodermal tumor, pituitary adenoma, and plasmacytoma. A panel of pertinent immunohistochemistry studies, histochemistries and/or molecular tests should aid in reaching a diagnosis, especially when taking the pattern and intensity of reactions into consideration.
\end{abstract}

Modern Pathology (2017) 30, S1-S26; doi:10.1038/modpathol.2016.119

\section{Introduction}

The sinonasal tract is affected by a wide variety of reactive and neoplastic conditions. The anatomy of the region is complex and difficult to visualize, even when radiographic images are employed. Biopsies are usually small and limited, resulting in considerable diagnostic difficulty for practicing surgical pathologists. Diagnoses are sought on smaller and smaller biopsies, many of which require additional studies to confirm the diagnosis or render management decisions (prognostication). There is a major emphasis on getting a definitive diagnosis on as little material as possible, with several overlapping histologic and immunophenotypic findings along with considerable variation within and between cases, making interpretation a daunting challenge, especially for pathologists who may not be as familiar with the diagnostic entities of these anatomic sites.

Correspondence: Dr LDR Thompson, MD Department of Pathology, Woodland Hills Medical Center, Southern California Permanente Medical Group, Woodland Hills, CA 91365, USA.

E-mail: Lester.D.Thompson@kp.org

Received 18 April 2016; revised 8 May 2016; accepted 15 May 2016
One such area is the 'small round blue cell' tumor category. This group of tumors encompasses a wide diversity of both benign and malignant neoplasms. The separation and distinction between tumors is critical as some are managed by conservative medical therapy, others by local surgery, a different group by primarily radiation, some by chemotherapy only, whereas others are managed by exenterative surgery and multimodality therapies, which can leave the patient potentially disfigured for life. It is, therefore, important to have a well developed differential diagnosis for this category, where each of the diagnoses is considered, evaluated, and either confirmed or excluded from further consideration. The major considerations are highlighted in Table 1, but this should be viewed as a guide, supplemented by good histology and appropriate dialogue with the treating clinicians. Although this approach is one I have found useful, there are several excellent reviews on this topic, ${ }^{1-6}$ the combination of which should help the reader in determining an approach that works for them.

\section{Approach}

In an undifferentiated tumor, showing a small round blue cell morphology, I find the mnemonic 
Table 1 Features to consider in a small round blue cell tumor evaluation

\begin{tabular}{|c|c|c|}
\hline Symptom duration & Unique/specific symptoms & Exact tumor location \\
\hline Bone destruction by imaging & Evidence of metastatic disease & Laboratory findings \\
\hline $\begin{array}{l}\text { Surface origin; pagetoid spread; junctional activity; } \\
\text { ulceration }\end{array}$ & $\begin{array}{l}\text { Dominant pattern of growth (lobular, ribbon, } \\
\text { trabecular, sheets, organoid, diffuse, } \\
\text { fascicular, alveolar) }\end{array}$ & $\begin{array}{l}\text { Tumor necrosis; geographic } \\
\text { necrosis; apoptosis }\end{array}$ \\
\hline Perineural invasion & Destructive bone invasion & Lymphovascular invasion \\
\hline Pleomorphism vs monotony & Cell size & Nuclear to cytoplasmic ratio \\
\hline $\begin{array}{l}\text { Cytoplasmic quality (clear, eosinophilic, amphophilic, } \\
\text { pigmented (melanin, lipofuscin, hemosiderin), } \\
\text { basophilic, vacuolated, granular, globules, inclusions) }\end{array}$ & $\begin{array}{l}\text { Cytoplasm location (even, plasmacytoid, } \\
\text { rhabdoid) }\end{array}$ & Intercellular bridges, borders \\
\hline Keratinization, dyskeratosis, squamous pearls/eddies & Mucin vacuoles & Glycogen granules \\
\hline Chromatin pattern/distribution & Nuclear molding & Nuclear cleaves, grooves, folds \\
\hline Intranuclear cytoplasmic inclusions & Nucleoli (prominent, small, absent) & Nuclear viral inclusions \\
\hline Background matrix & True rosettes (Flexner-Wintersteiner) & Pseudorosettes (Homer Wright) \\
\hline Neural matrix & Desmoplasia/reactive fibrosis & Inflammatory infiltrate \\
\hline
\end{tabular}

'MR SLEEP' or 'MRS LEEP' to be helpful, as it highlights a series of tumors that must be considered in the differential diagnosis: melanoma, mesenchymal chondrosarcoma, rhabdomyosarcoma, sinonasal undifferentiated carcinoma (SNUC), squamous cell carcinoma (including NUT carcinoma), small cell osteosarcoma, lymphoma, esthesioneuroblastoma (olfactory neuroblastoma), Ewing sarcoma/primitive neuroectodermal tumor, pituitary adenoma, and plasmacytoma (Table 2). There are obviously tumors that are more common than others, and these should be more carefully excluded. It is important to select a panel of immunohistochemistry studies during the initial evaluation in order to avoid misclassification; the antibodies may include an epithelial marker (pancytokeratin such as AE1/AE3, epithelial membrane antigen (EMA) or OSCAR), a neuroendocrine marker (synaptophysin, chromogranin, or CD56), a muscle marker (desmin, myogenin, MYOD1), S100 protein, and CD45RB. The patterns of reactivity would then help to guide additional studies, as suggested by the histologic features, combined with the clinical and imaging findings. The following is a brief discussion of the pertinent findings of each of the major tumors in this site that can show a small round blue cell morphology.

\section{Specific tumors}

\section{Melanoma}

Mucosal melanoma arises within the sinonasal tract from melanocytes within the mucosa, representing about $4 \%$ of all sinonasal tract tumors. ${ }^{7-9}$

Clinical. With an equal sex distribution, there is a wide age range but more common in elderly (7th decade) patients (Table 2). ${ }^{7,9}$ Symptoms are non-specific, with melanorrhea (black flecked secretions) uncommon. A mass usually affects the sinonasal cavity (septum) more often than the paranasal sinuses. ${ }^{10}$
Histopathology. When surface involvement or pagetoid spread is present (Figure 1a and b), a mucosal melanoma is much easier to diagnose. However, there is frequently surface ulceration, precluding junctional assessment. A peritheliomatous distribution of slightly dyscohesive cells is quite characteristic at low power (Figure 1c), but it is not specific. Tumor necrosis is common, as are easily identified and increased mitoses. The morphologic features are protean, but usually some of the cells will show eccentric nuclei, intranuclear cytoplasmic inclusions, prominent nucleoli, and/or cytoplasmic pigmentation (Figure 1d). The variable morphologies within a single tumor may help with the diagnosis, with cells ranging from undifferentiated to epithelioid, spindled, plasmacytoid, and rhabdoid, all in the same tumor.

Special studies. When pigmentation is absent, immunohistochemistry becomes helpful, with S100 protein and SOX10 usually strongly and diffusely reactive, whereas other melanocytic markers (HMB45, tyrosinase, melan A, MITF) are expressed to a variable degree, often based on tumor morphology; $6,7,11,12$ in undifferentiated tumors, scant cytoplasm may result in focal or negative reactions, requiring careful high-power examination. Crossreactivity with neuroendocrine markers is rare. ${ }^{12} \mathrm{In}$ general, RAS and then KIT mutations (mutually exclusive) are detected at a distinctly higher rate than cutaneous melanomas, with BRAF mutations rarely detected. ${ }^{13-15}$

Outcome and management. Theoretically, cutaneous primary melanoma may present with sinonasal mucosal metastasis, but practically are vanishingly rare, with melanoma in the sinonasal tract considered primary. In spite of multimodality therapy (including targeted treatments), due to high stage at presentation, there is an overall poor survival of $<30 \%$ at 5 years. ${ }^{7,11,16-18}$ Depth of invasion and tumor thickness do not apply in sinonasal tract tumors. 
Table 2 Immunohistochemical reactivity of small, round, blue cell tumors of the sinonasal tract (in mnemonic order: MR SLEEP)

\begin{tabular}{|c|c|c|c|c|c|c|c|c|c|}
\hline & $\begin{array}{l}\text { Mucosal } \\
\text { melanoma }\end{array}$ & Rhabdomyosarcoma & $\begin{array}{l}\text { Sinonasal } \\
\text { undifferentiated } \\
\text { carcinoma }\end{array}$ & NUT carcinoma & $\begin{array}{l}\text { Neuroendocrine } \\
\text { carcinoma }\end{array}$ & $\begin{array}{l}\text { Extranodal NK/ } \\
\text { T-cell lymphoma, } \\
\text { nasal type }\end{array}$ & $\begin{array}{l}\text { Olfactory } \\
\text { neuroblastoma }\end{array}$ & Ewing sarcoma & $\begin{array}{l}\text { Pituitary } \\
\text { adenoma }\end{array}$ \\
\hline Pattern & $\begin{array}{l}\text { Protean, solid, } \\
\text { organoid, } \\
\text { fascicular }\end{array}$ & Sheets, alveolar & Sheets, nests & Sheets, nests & $\begin{array}{l}\text { Syncytial, } \\
\text { islands, ribbons } \\
\text { sheets }\end{array}$ & Diffuse & Lobular & Sheets, nests & $\begin{array}{l}\text { Sheets, rosettes, } \\
\text { trabecular }\end{array}$ \\
\hline $\begin{array}{l}\text { Morphologic } \\
\text { features }\end{array}$ & $\begin{array}{l}\text { Large, } \\
\text { polygonal, } \\
\text { epithelioid, } \\
\text { rhabdoid, } \\
\text { plasmacytoid, } \\
\text { spindle cells; } \\
\text { pigment, } \\
\text { pleomorphism, } \\
\text { high mitotic } \\
\text { count, limited } \\
\text { necrosis, rare } \\
\text { vascular } \\
\text { invasion, surface } \\
\text { involvement, no } \\
\text { neurofibrillary } \\
\text { matrix }\end{array}$ & $\begin{array}{l}\text { Round, strap, } \\
\text { spindled, } \\
\text { rhabdomyoblasts, } \\
\text { primitive cells, } \\
\text { pleomorphism } \\
\text { present, variable } \\
\text { mitoses, limited } \\
\text { necrosis, rare } \\
\text { lympho- } \\
\text { vascular invasion, } \\
\text { no neurofibrillary } \\
\text { matrix or rosettes }\end{array}$ & $\begin{array}{l}\text { Medium cells, } \\
\text { inconspicuous } \\
\text { nucleoli, } \\
\text { pleomorphism, } \\
\text { high mitotic } \\
\text { count, } \\
\text { prominent } \\
\text { necrosis, } \\
\text { lympho- } \\
\text { vascular } \\
\text { invasion, no } \\
\text { neurofibrillary } \\
\text { stroma, } \\
\text { pseudorosettes } \\
\text { usually absent }\end{array}$ & $\begin{array}{l}\text { Medium cells, } \\
\text { monotonous, } \\
\text { high nuclear } \\
\text { to cytoplasmic } \\
\text { ratio, abrupt } \\
\text { keratinization } \\
\text { or squamous } \\
\text { differentiation, } \\
\text { high mitotic } \\
\text { count, tumor } \\
\text { necrosis }\end{array}$ & $\begin{array}{l}\text { Small cells, with } \\
\text { high nuclear: } \\
\text { cytoplasmic } \\
\text { ratio, nuclear } \\
\text { molding, nuclei } \\
\text { crushed, } \\
\text { moderate } \\
\text { pleomorphism, } \\
\text { inconspicuous } \\
\text { nucleoli, high } \\
\text { mitotic count, } \\
\text { necrosis, no } \\
\text { neurofibrillary } \\
\text { matrix, } \\
\text { pseudorosettes } \\
\text { may present }\end{array}$ & $\begin{array}{l}\text { Polymorphous, } \\
\text { small to large cells, } \\
\text { folded, cleaved } \\
\text { and grooved } \\
\text { nuclei, } \\
\text { pleomorphism, } \\
\text { high mitotic count, } \\
\text { necrosis, lympho- } \\
\text { vascular invasion, } \\
\text { no neurofibrillary } \\
\text { matrix or rosettes }\end{array}$ & $\begin{array}{l}\text { Salt-and-pepper } \\
\text { chromatin, } \\
\text { small nucleoli } \\
\text { (grade } \\
\text { dependent), } \\
\text { limited mitoses, } \\
\text { scant necrosis, } \\
\text { neurofibrillary } \\
\text { matrix present, } \\
\text { pseudorosettes } \\
\text { and true rosettes }\end{array}$ & $\begin{array}{l}\text { Medium, round } \\
\text { cells, vacuolated } \\
\text { cytoplasm, fine } \\
\text { chromatin, scant } \\
\text { pleomorphism, } \\
\text { easily identified } \\
\text { mitoses, } \\
\text { necrosis, limited } \\
\text { to absent } \\
\text { lympho- } \\
\text { vascular } \\
\text { invasion, no } \\
\text { neurofibrillary } \\
\text { matrix, rosettes } \\
\text { often present }\end{array}$ & $\begin{array}{l}\text { Small cells, } \\
\text { no perineural } \\
\text { or vascular } \\
\text { invasion, } \\
\text { may have } \\
\text { pleomorphism, } \\
\text { limited mitoses, } \\
\text { necrosis can } \\
\text { be seen, no } \\
\text { neurofibrillary } \\
\text { matrix }\end{array}$ \\
\hline $\begin{array}{l}\text { CK-pan } \\
\text { (AE1/AE3) }\end{array}$ & $\mathrm{N}$ & $\begin{array}{l}\text { S (up to } 10 \% \text {; } \\
\text { weak; punctate/ } \\
\text { dot) }\end{array}$ & $\mathrm{P}$ & $\mathrm{P}$ & P (dot/punctate) & $\mathrm{N}$ & $\begin{array}{l}\mathrm{R} \text {, focal and } \\
\text { weak }\end{array}$ & $\mathrm{R}(<30 \%)$ & $\begin{array}{l}\mathrm{P}(80 \% ; \text { dot} / \\
\text { punctate) }\end{array}$ \\
\hline CK5/6 & $\mathrm{N}$ & $\mathrm{N}$ & $\mathrm{N}$ & $\mathrm{P}$ & R (dot/punctate) & $\mathrm{N}$ & $\mathrm{N}$ & $\mathrm{N}$ & $\mathrm{N}$ \\
\hline CK7 & $\mathrm{N}$ & $\mathrm{N}$ & $\mathrm{P}(\sim 50 \%)$ & S (40\%) & $\mathrm{R}$ & $\mathrm{N}$ & $\mathrm{N}$ & $\mathrm{N}$ & $\mathrm{R}$ \\
\hline EMA & $\mathrm{R}$ & $\mathrm{R}(<1 \%)$ & $\mathrm{P}(\sim 50 \%)$ & $\mathrm{S}(30 \%)$ & $\mathrm{P}$ & $\mathrm{N}$ & $\mathrm{R}$ (focal only) & $\mathrm{R}(<20 \%)$ & $\mathrm{N}$ \\
\hline CAM5.2 & $\mathrm{R}$ & $\begin{array}{l}\text { S (up to } 50 \% \text {, focal, } \\
\text { weak) }\end{array}$ & $\mathrm{S}$ & $\mathrm{P}(50 \%)$ & P (dot/punctate) & $\mathrm{N}$ & R (focal only) & $\begin{array}{l}\mathrm{R} \text { (focal to } \\
\text { diffuse, } 20 \% \text { ) }\end{array}$ & $\mathrm{P}$ \\
\hline p63 & $\mathrm{N}$ & $\mathrm{N}$ & $\mathrm{S}(20 \%)$ & $\mathrm{P}$ & R (weak) & $\mathrm{R}$ & $\mathrm{R}$ & $\mathrm{S}$ & $\mathrm{N}$ \\
\hline $\mathrm{p} 40$ & $\mathrm{~N}$ & $\mathrm{~N}$ & $\mathrm{~N}$ & $\mathrm{P}$ & $\mathrm{N}$ & $\mathrm{N}$ & $\mathrm{N}$ & $\mathrm{N}$ & $\mathrm{N}$ \\
\hline Synaptophysin & $\mathrm{N}$ & $\begin{array}{l}\mathrm{R} \text { (up to } 30 \% \text {, } \\
\text { weak) }\end{array}$ & $\mathrm{S}(<15 \%)$ & $\mathrm{S}(<15 \%)$ & $\mathrm{P}$ & $\mathrm{N}$ & P (may be weak) & S (focal) & $\mathrm{P}$ \\
\hline Chromogranin & $\mathrm{N}$ & $\begin{array}{l}\mathrm{R} \text { (up to } 20 \% \text {, } \\
\text { weak) }\end{array}$ & $\mathrm{S}(<10 \%)$ & $\mathrm{S}(<15 \%)$ & $\mathrm{P}$ & $\mathrm{N}$ & P (may be weak) & $\mathrm{R}$ (2\%, focal) & $\mathrm{P}$ \\
\hline CD56 & $\mathrm{N}$ & $\mathrm{P}$ & $S(<5 \%)$ & $\mathrm{N}$ & $\mathrm{P}$ & $\mathrm{P}$ & P (membrane) & $\mathrm{R}(10 \%$, focal $)$ & $\mathrm{P}$ \\
\hline NSE & $\mathrm{N}$ & R (up to $8 \%$ ) & $\mathrm{P}$ & $\mathrm{n} / \mathrm{r}$ & $\mathrm{P}$ & $\mathrm{N}$ & $\mathrm{P}$ & $\mathrm{P}$ & $\mathrm{P}$ \\
\hline CD99 & $\mathrm{N}$ & $\mathrm{R}$ (up to $20 \%$ ) & $\mathrm{S}(<10 \%)$ & S (30\%) & $\mathrm{N}$ & $\mathrm{R}$ & $\mathrm{N}$ & $\mathrm{P}$ & $\mathrm{S}(\sim 30 \%)$ \\
\hline p16 & $\mathrm{N}$ & $\mathrm{R}(<10 \%)$ & $\mathrm{P}$ & $\mathrm{P}$ & $\mathrm{P}$ & $\mathrm{N}$ & $\mathrm{N}$ & $\mathrm{P}$ & $\mathrm{N}$ \\
\hline FLI-1 & $\mathrm{P}$ & R (focal) & $\mathrm{n} / \mathrm{r}$ & $\mathrm{n} / \mathrm{r}$ & R (focal) & $\mathrm{n} / \mathrm{r}$ & $\mathrm{R}$ & $\mathrm{P}(\sim 75 \%)$ & $\mathrm{n} / \mathrm{r}$ \\
\hline
\end{tabular}


Table 2 (Continued)

\begin{tabular}{|c|c|c|c|c|c|c|c|c|c|}
\hline & $\begin{array}{l}\text { Mucosal } \\
\text { melanoma }\end{array}$ & Rhabdomyosarcoma & $\begin{array}{l}\text { Sinonasal } \\
\text { undifferentiated } \\
\text { carcinoma }\end{array}$ & NUT carcinoma & $\begin{array}{l}\text { Neuroendocrine } \\
\text { carcinoma }\end{array}$ & $\begin{array}{l}\text { Extranodal NK/ } \\
\text { T-cell lymphoma, } \\
\text { nasal type }\end{array}$ & $\begin{array}{l}\text { Olfactory } \\
\text { neuroblastoma }\end{array}$ & Ewing sarcoma & $\begin{array}{l}\text { Pituitary } \\
\text { adenoma }\end{array}$ \\
\hline Calcitonin & $\mathrm{N}$ & $\mathrm{N}$ & $\mathrm{N}$ & $\mathrm{N}$ & $\mathrm{R}$ & $\mathrm{N}$ & $\mathrm{N}$ & $\mathrm{N}$ & S $(20 \%)$ \\
\hline S100 protein & $\mathrm{P}$ & $\mathrm{R}$ & $\mathrm{R}$ & R (focal, weak) & $\mathrm{R}$ & $\mathrm{N}$ & $\begin{array}{l}\text { P (sustentacular } \\
\text { only) }\end{array}$ & $\begin{array}{l}\mathrm{S} \text { (up to } 30 \% \text {, } \\
\text { focal) }\end{array}$ & $\mathrm{R}$ (focal, weak) \\
\hline SOX10 & $\mathrm{P}$ & $\mathrm{N}$ & $\mathrm{N}$ & $\mathrm{N}$ & $\mathrm{N}$ & $\mathrm{N}$ & $\begin{array}{l}\text { P (sustentacular } \\
\text { only) }\end{array}$ & $\mathrm{N}$ & $\mathrm{N}$ \\
\hline HMB45 & $\mathrm{P}$ & $\mathrm{N}$ & $\mathrm{N}$ & $\mathrm{N}$ & $\mathrm{N}$ & $\mathrm{N}$ & $\mathrm{N}$ & $\mathrm{N}$ & $\mathrm{N}$ \\
\hline GFAP & $\mathrm{N}$ & $\mathrm{N}$ & $\mathrm{N}$ & $\mathrm{N}$ & $\mathrm{N}$ & $\mathrm{N}$ & $\begin{array}{l}\text { P (sustentacular } \\
\text { only) }\end{array}$ & $\begin{array}{l}\mathrm{R} \text { (up to } 20 \% \text {, } \\
\text { focal) }\end{array}$ & $\mathrm{N}$ \\
\hline Calretinin & $\mathrm{R}$ & $\mathrm{N}$ & $\mathrm{N}$ & $\mathrm{n} / \mathrm{r}$ & $S$ & $\mathrm{R}$ & $\mathrm{P}$ & $\begin{array}{l}\mathrm{R} \text { (up to } 15 \% \text {, } \\
\text { focal) }\end{array}$ & $\mathrm{P}$ \\
\hline CD45RB & $\mathrm{N}$ & $\mathrm{R}(<5 \%)$ & $\mathrm{N}$ & $\mathrm{N}$ & $\mathrm{N}$ & $\mathrm{P}$ & $\mathrm{N}$ & $\mathrm{N}$ & $\mathrm{N}$ \\
\hline Vimentin & $\mathrm{P}$ & $\mathrm{P}$ & $\mathrm{N}$ & $\mathrm{S}$ & $S$ & $\mathrm{P}$ & $\mathrm{R}$ & $\mathrm{P}$ & $\mathrm{N}$ \\
\hline Myogenin & $\mathrm{N}$ & $P$ & $\mathrm{~N}$ & $\mathrm{~N}$ & $\mathrm{~N}$ & $\mathrm{~N}$ & $\mathrm{~N}$ & $\mathrm{~N}$ & $\mathrm{~N}$ \\
\hline CD117 & S & $\mathrm{R}(<15 \%)$ & $\mathrm{P}$ & $\mathrm{N}$ & $\mathrm{P}$ & $\mathrm{N}$ & $\mathrm{N}$ & $\mathrm{S}(\sim 35 \%)$ & $\mathrm{S}(50 \%)$ \\
\hline Pituitary $^{\mathrm{a}}$ & R (hormones) & $\mathrm{N}$ & $\mathrm{N}$ & $\mathrm{N}$ & $\mathrm{N}$ & $\mathrm{N}$ & $\mathrm{N}$ & $\mathrm{N}$ & $\mathrm{P}$ \\
\hline TTF-1 & $\mathrm{N}$ & $\mathrm{N}$ & $\mathrm{N}$ & $\mathrm{R}$ & $\mathrm{P}$ & $\mathrm{N}$ & $\mathrm{N}$ & $\mathrm{R}$ & $\mathrm{N}$ \\
\hline EBER (ISH) & $\mathrm{N}$ & $\mathrm{N}$ & $\mathrm{N}$ & $\mathrm{N}$ & $\mathrm{N}$ & $\mathrm{P}(\sim 100 \%)$ & $\mathrm{N}$ & $\mathrm{N}$ & $\mathrm{N}$ \\
\hline NUT IHC & $\mathrm{N}$ & $\mathrm{N}$ & $\mathrm{N}$ & $\mathrm{P}$ & $\mathrm{N}$ & $\mathrm{N}$ & $\mathrm{N}$ & $\mathrm{N}$ & $\mathrm{N}$ \\
\hline
\end{tabular}

Abbreviations: N, negative; NEC, neuroendocrine carcinoma; n/r, not reported; ONB, olfactory neuroblastoma; P, almost always positive; R, rarely positive; RMS, rhabdomyosarcoma; S, sometimes

positive; SNUC, sinonasal undifferentiated carcinoma.

Based on data aggregate in part from Bahrami et al, ${ }^{36}$ Bell et al, ${ }^{15}$ Bishop et al,,${ }^{74}$ Bourne et al, ${ }^{143}$ Chapman-Fredricks et al, ${ }^{88}$ Folpe et al, ${ }^{151}$ Hafezi et al, ${ }^{150}$ Hicks et al, ${ }^{30}$ Nikitakis et al, ${ }^{166}$ Thompson et al, ${ }^{7}$ Thompson et al, ${ }^{124}$ Thompson et al, ${ }^{159}$ and Wooff et al. ${ }^{57}$ 

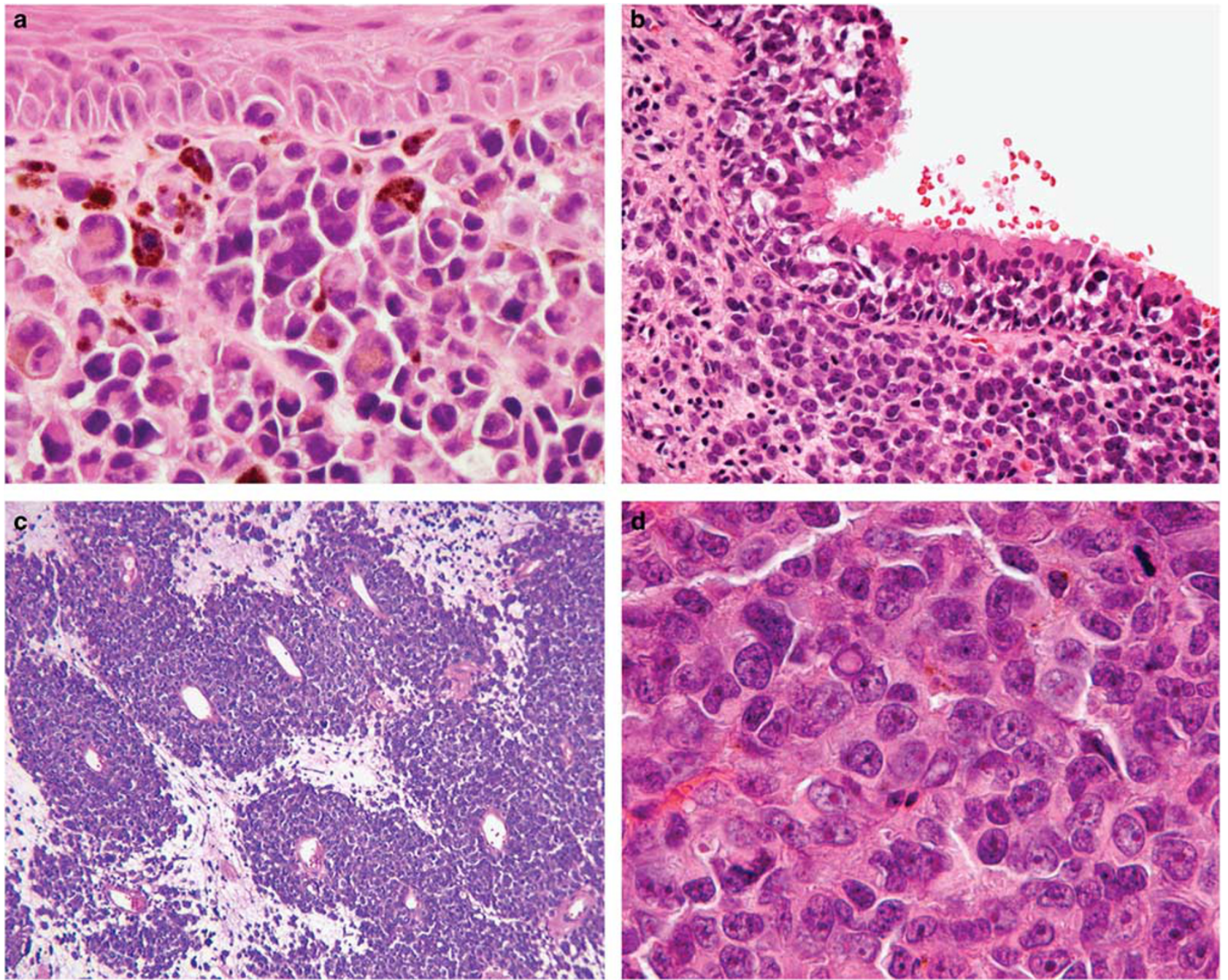

Figure 1 Mucosal melanoma. Surface involvement by neoplastic and pleomorphic, pigmented melanocytes (a) are much easier to diagnose than the small round blue cell pattern often seen (b), although surface involvement is helpful. A peritheliomatous distribution of slightly dyscohesive cells (c) is a characteristic finding. The cells are large, with prominent nucleoli, intranuclear cytoplasmic inclusions and focal pigmentation (d).

\section{Mesenchymal Chondrosarcoma}

Mesenchymal chondrosarcoma is a rare malignancy with a biphasic small round blue cell proliferation associated with islands of differentiated hyaline cartilage. The proportion of cartilage may be exceedingly limited, requiring careful evaluation of all tissue, sometimes with multiple serial sections or deeper levels required.

Clinical. With an equal sex distribution, tumors present most commonly in the 2nd to 4th decades, with craniofacial bones frequently affected (about $13 \%$ ), although usually jaws, often with soft tissue extension. ${ }^{19-22}$

Histopathology. The tumor always shows the small blue round cell component, although the proportions of cells to differentiated cartilage varies (Figure 2).
The cartilage must be neoplastic rather than native cartilage of the sinonasal tract being destroyed by the tumor. The cells are arranged in solid sheets, frequently around a prominent, hemangiopericytomalike vascularity. The small cells have ovoid, hyperchromatic nuclei with scant cytoplasm, although they often show a spindled morphology. Tumor necrosis is uncommon, but mitoses, including atypical forms are easily identified and increased.

Special studies. The neoplastic cells are positive with antibodies to CD99, CD56, NSE, variably with glial filament acidic protein (GFAP), desmin, and synaptophysin, whereas non-reactive with keratins and S100 protein. One of the most helpful markers is strong nuclear expression for SOX9, a regulator of chondrogenesis, non-reactive in the other small round blue cell tumors. ${ }^{23,24}$ Further, about $80 \%$ of tumors show HEY1-NCOA2 fusions by FISH. ${ }^{25}$ 

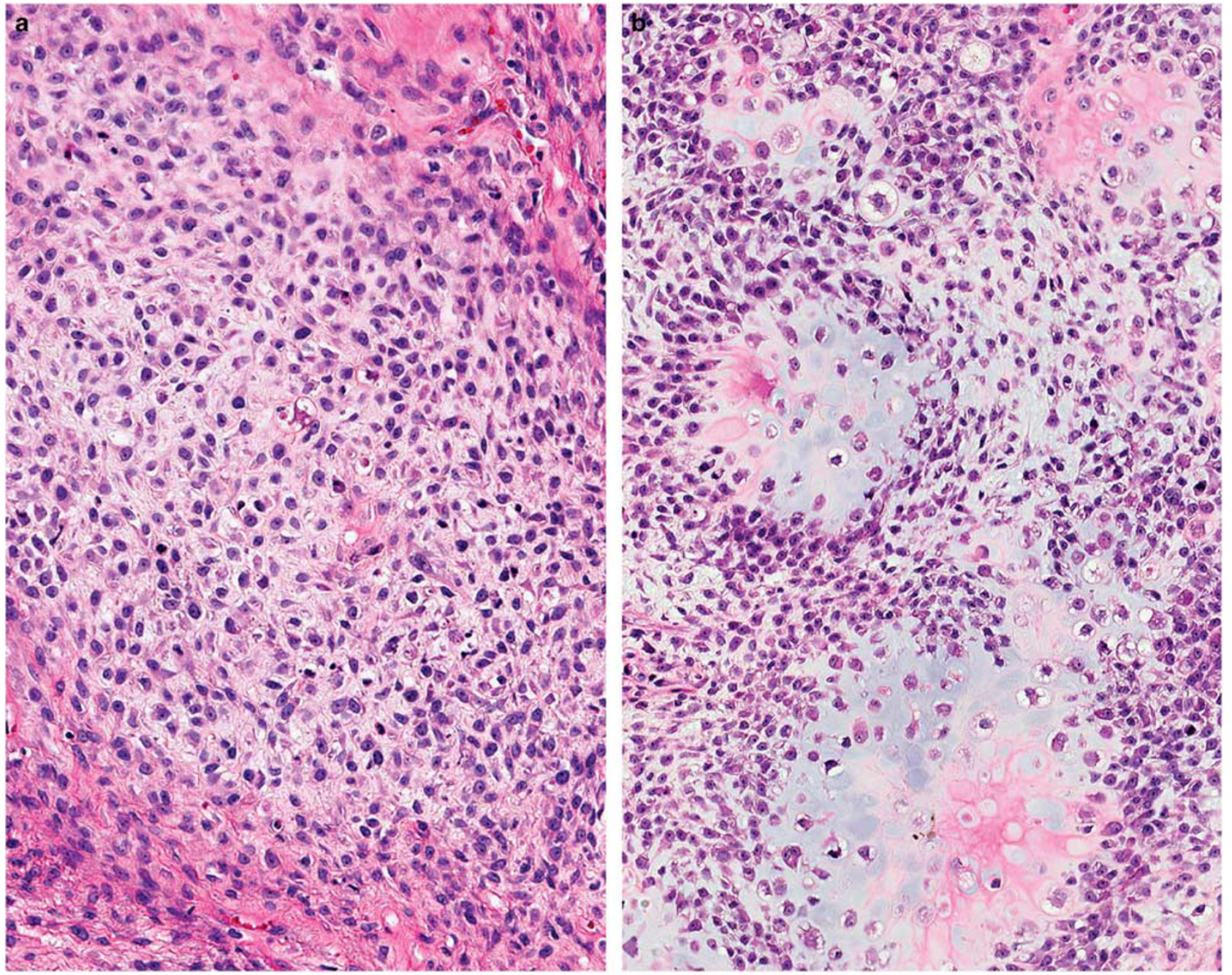

Figure 2 Mesenchymal chondrosarcoma. There is a small round blue cell to spindled appearance without well-developed cartilage (a), although neoplastic hyaline cartilage is surrounded by a small round blue cell component in this sinonasal tract tumor (b).

Outcome and management. Complete resection and chemotherapy yield an excellent median overall survival (17 years), whereas metastases at presentation has the strongest negative impact on survival. Mandatory long-term follow-up is required due to late recurrences. ${ }^{21}$

\section{Rhabdomyosarcoma}

Sinonasal rhabdomyosarcoma are rare malignant tumors showing skeletal muscle differentiation. Although several subtypes are recognized, the alveolar type is included specifically in the small round blue cell differential. ${ }^{26-28}$

Clinical. Rhabdomyosarcoma, although uncommon, is still the most common sinonasal sarcoma, ${ }^{29-31}$ with a slight female to male predilection (1.2:1). ${ }^{32}$ In adults, alveolar rhabdomyosarcoma is the most common subtype in the sinonasal tract. Syndrome association (Li-Fraumeni, Costello, and neurofibromatosis type 1) may be seen in children. ${ }^{33}$ Symptoms are non-specific, with polyps, obstruction, facial swelling, proptosis, and epistaxis (Figure 3a). The paranasal sinuses are affected most commonly, with extension into the nasal cavity, orbit and skull base. ${ }^{27,34,35}$

Histopathology. Most lesions present as polyps, with a tan-grey cut surface. The embryonal type is the most common in the sinonasal tract, but in the small round blue cell differential, the alveolar type is considered. Fibrovascular septa separate the tumor into nests of small to medium round cells, which aggregate in the center, showing a clinging dilapidated appearance at the fibrous septa (Figures 3 and 4). Apoptotic, degenerated cells coalesce in the center of the alveolar spaces, often associated with tumor necrosis. A characteristic plasmacytoidrhabdoid appearance, with eccentric, eosinophilic cytoplasm strongly suggests ribbon or strap-type 

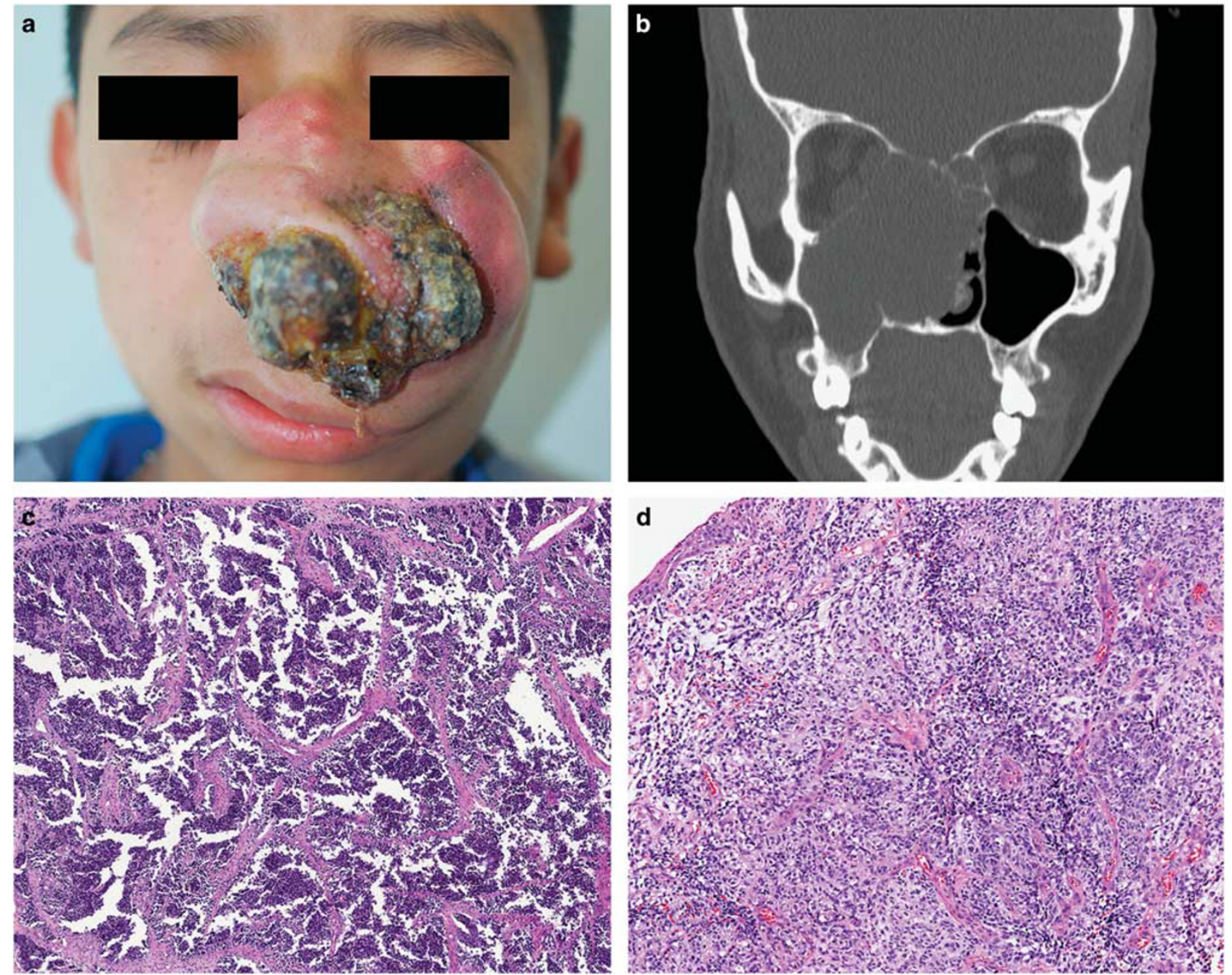

Figure 3 Rhabdomyosarcoma. (a) A large destructive mass of the nasal cavity, expanding into the soft tissues (photo courtesy Dr R Carlos). (b) A large destructive midline mass on computed tomography, expanding into the maxillary sinus. The low-power alveolar pattern with fibrous septa (c) helps in the differential diagnosis of this tumor. A slightly more epithelioid pattern is seen in this rhabdomyosarcoma (d).

rhabdomyoblasts (Figure 4c and d). Nucleoli are inconspicuous. Mitoses are usually easy to identify.

Special studies. The neoplastic cells are usually positive with desmin and myogenin (Myf-4; Figure 5a and b), with Myo-D1 and muscle-specific actin less frequently positive; smooth muscle actin is only detected in about $10 \%$ of cases. ${ }^{30}$ Co-expression of CD56, synaptophysin (Figure 5c), cytokeratins (up to $10 \%$; Figure 5d), EMA, NSE, and CD99, ${ }^{30,36-38}$ must be taken into account in differential diagnosis, especially when choosing a panel of immunohistochemistry studies to perform. A FISH breakapart probe for FOXO1 (13q14) may help to confirm the commonly identified fusion with $P A X 3$ or $P A X 7$ genes in alveolar rhabdomyosarcoma. ${ }^{38,39}$

Outcome and management. Rhabdomyosarcoma is considered a systemic disease, managed with multimodality therapies including surgery, chemotherapy and radiation, ${ }^{40}$ frequently associated with adverse late sequela of treatment. ${ }^{41}$ There is an overall poor prognosis of sinonasal tract alveolar rhabdomyosarcoma (5-year survival $30-40 \%),{ }^{29,35,41-44}$ with patients frequently showing regional and/or distant metastases, although young patients (5-year survival $62.5 \%$ ) tend to have a better prognosis. ${ }^{28,32,43}$

\section{Sinonasal Undifferentiated Carcinoma (SNUC)}

SNUC is a rare tumor, lacking glandular or squamous features, and is not otherwise classifiable. Thus, it is a tumor of exclusion, comprising $3-5 \%$ of all sinonasal tract carcinomas. ${ }^{45-47}$

Clinical. Affecting a wide age range, the tumor is most common in 50-60 year olds, with men affected much more frequently than women ${ }^{45-49}$ Often with a rapid clinical presentation, obstructive symptoms 

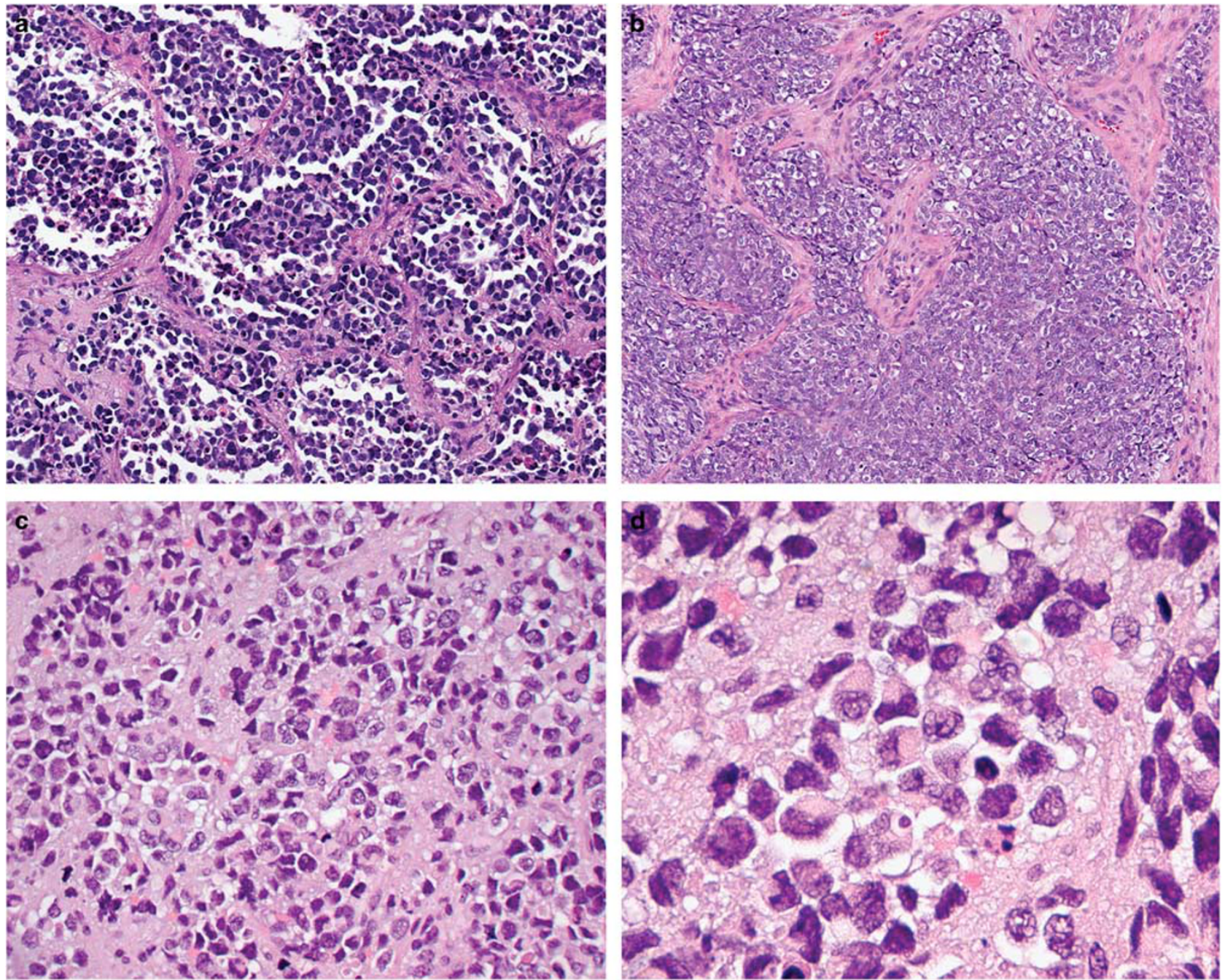

Figure 4 Alveolar rhabdomyosarcoma. Alveolar spaces (a) with dyscohesive dilapidated cells in the center, with clinging cells on the fibrous septa. A more solid appearance (b) may be seen in rhabdomyosarcoma. The neoplastic cells show a plasmacytoid (c) to rhabdoid appearance. There is moderate to severe nuclear pleomorphism (d), with well-developed rhabdoid/plasmacytoid cells noted.

are related to tumor presentation as large, midline widely destructive masses, starting in the nasal cavity, but rapidly expanding into adjacent sites $\left(60 \%\right.$ have orbit or skull base extension) ${ }^{48-50}$

Histopathology. Tumors are usually large $(>4 \mathrm{~cm})$ at the time of initial clinical presentation, showing ulceration, bone destruction, lymphovascular invasion, perineural invasion, and extensive necrosis. The cellular tumors are arranged in sheets, lobules, and trabeculae of atypical, but monotonous polygonal cells, showing round to irregular nuclei, welldefined cell borders and ample cytoplasm (Figure 6). The nuclear chromatin is vesicular to open with prominent nucleoli. Neuroendocrine morphologic features are absent. Apoptosis and increased mitoses are easily identified. By definition, squamous or glandular differentiation is absent, but in some cases surface dysplasia or carcinoma in situ may be seen.
Rosettes may be present. ${ }^{4,45,49-53}$ When more basaloid growth and rhabdoid features are present, the lack of SMARCB1 (INI-1) protein by immunohistochemistry may suggest a different tumor type..$^{54,55}$

Special studies. There is a strong and diffuse expression of epithelial markers (AE1/AE3, CK7, OSCAR, CAM5.2, EMA; Figure 6), consistent p16 and CD117 reactions, and only focal, patchy nuclear reaction with p63, whereas CK5/6, p40, CEA, EBER, CD34, desmin, S100 protein, and calretinin are consistently negative. ${ }^{53,56-61}$ Focal, patchy, and/or weak reactions with neuroendocrine markers (NSE, synaptophysin, chromogranin, CD56) may be present, but there is no corresponding neuroendocrine morphology.

Outcome and management. The overall prognosis is poor, but with aggressive multimodality therapy, 

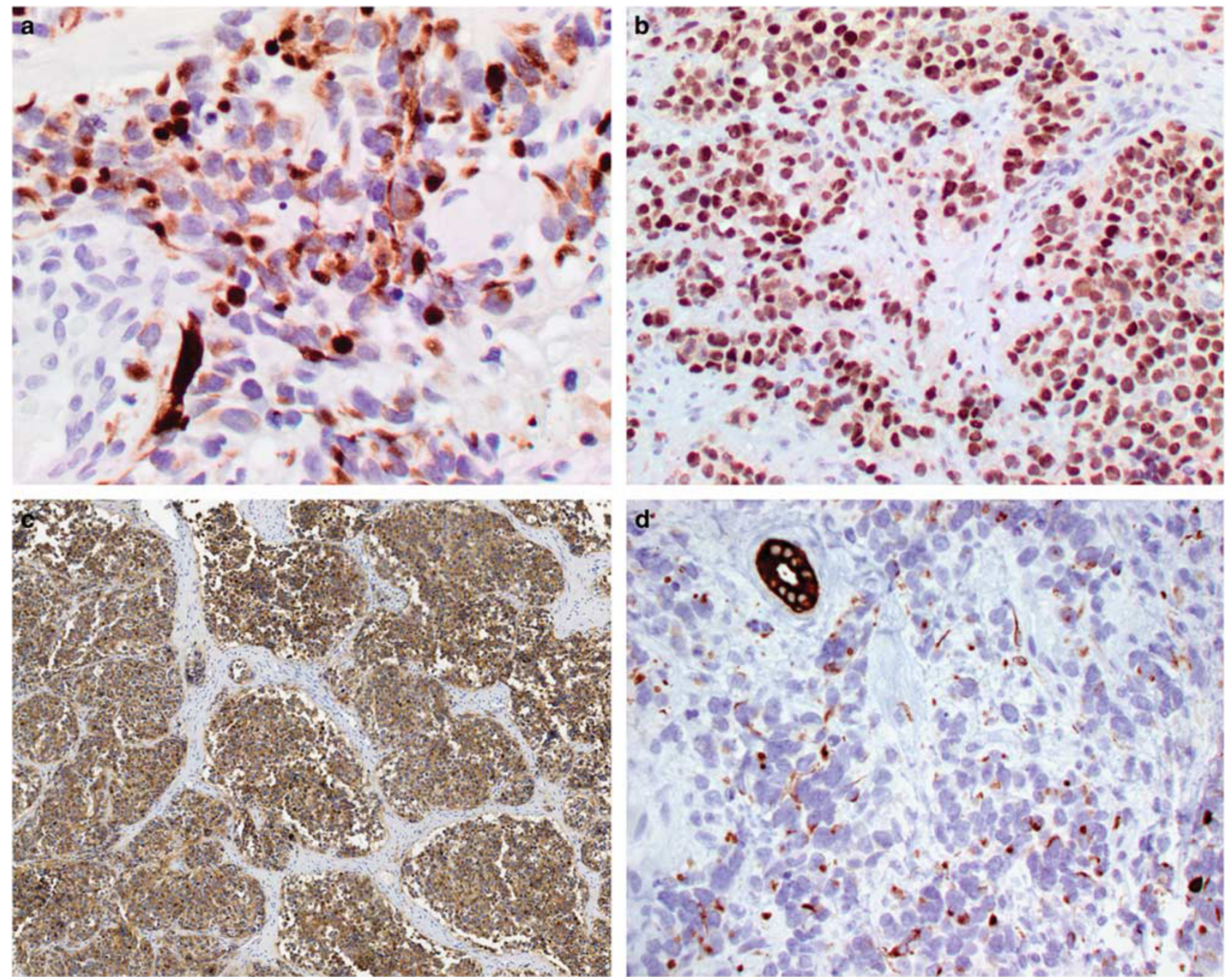

Figure 5 Alveolar rhabdomyosarcoma. The neoplastic cells show positive reactions with desmin in the cytoplasm (a), myogenin in the nuclei (b), although synaptophysin (c) and pancytokeratin (d) may be aberrantly expressed.

including primary surgical resection, 5-year survival rates or $35-63 \%$ are achieved, but with a median overall survival of about 2 years. ${ }^{46-49,53,60,62-66}$ Local recurrence is common, but nodal metastases are relatively uncommon, although distant metastases are frequent.

\section{NUT Carcinoma (Squamous Cell Carcinoma)}

NUT carcinoma is a poorly differentiated carcinoma that shows abrupt evidence of squamous differentiation, defined by the presence of NUTM1 gene rearrangement (nuclear protein in testis). This very rare malignancy is suggested morphologically by the abrupt keratinization but can only be confirmed by NUTM1 detection.

Clinical. Sinonasal tract involvement by NUT carcinoma is much less common than mediastinal disease, but most head and neck cases affect the nasal cavity and paranasal sinuses (65\%), with a median presentation in the $20 \mathrm{~s}$, showing a slight female predominance. ${ }^{67-73}$ There is no known etiologic association. Patients present with a rapidlygrowing, extensively destructive mass, often with orbital involvement, and lymph node metastases in about $50 \%$ of patients. ${ }^{70,73,74}$

Histopathology. The tumors invade as sheets of monotonously undifferentiated cells, frequently showing bone invasion and tumor necrosis (Figure 7). The undifferentiated cells have moderate cytoplasm (occasionally clear) surrounding round to oval nuclei with vesicular chromatin and distinct, but small nucleoli. Characteristically, there are areas of abrupt keratinization or squamous differentiation (Figure 7), occasionally showing more extensive squamous features. Usually, careful, high-power review is required to see these areas. Rarely, 

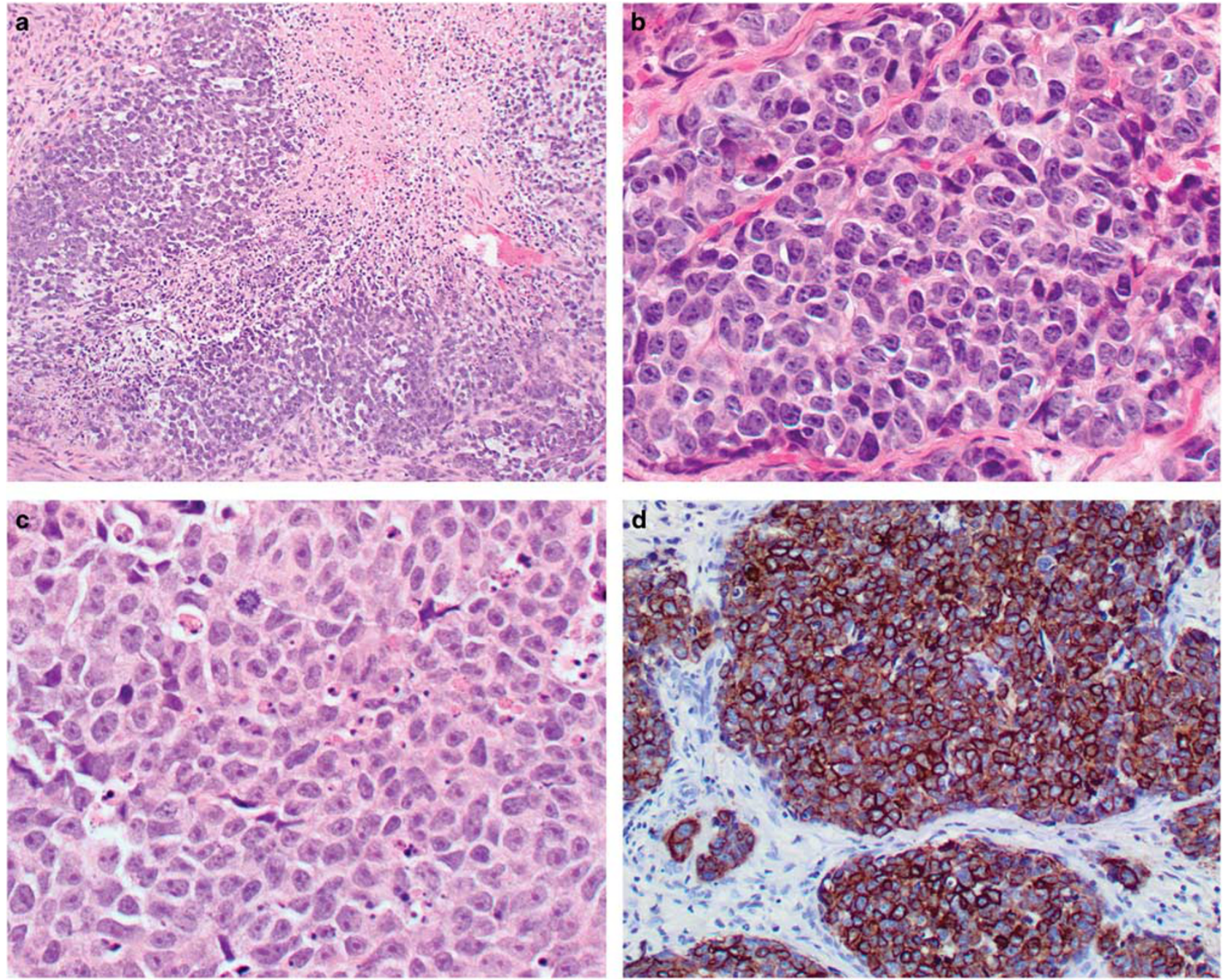

Figure 6 Sinonasal undifferentiated carcinoma. The neoplastic cells are medium, associated with tumor necrosis (a). The cells are arranged in sheets and nests (b), comprised of cells that have a high nuclear to cytoplasmic ratio, vesicular to open nuclear chromatin, and often prominent nucleoli (c). Mitoses are easily identified. The neoplastic cells are strongly reactive with pancytokeratin (d).

glandular or mesenchymal differentiation may be present. Acute inflammation within the neoplasm can be quite brisk.

Special studies. The neoplastic cells will be positive with pancytokeratin (AE1/AE3), along with CK5/6, p63 and p40, ${ }^{69,70,75}$ frequently with CD34 $(55 \%)^{76}$, and uncommonly with neuroendocrine markers, p16 and TTF-1. By definition, NUTM1 rearrangement must be documented, which can be achieved by strong, diffuse ( $>50 \%$ ) nuclear staining with the NUT monoclonal antibody (C52, Cell Signaling Technologies, Inc.; Figure 7$),{ }^{75,77}$ or by other methodologies (FISH, reverse-transcriptase PCR, targeted next-generation sequencing).

Outcome and management. Conventional treatments are ineffective, which yields a poor overall prognosis of about 10 months (median survival). ${ }^{73}$ Molecular targeted therapies with pharmacogenomic agents may yield growth arrest and prolonged survival, but blood-brain barrier limitations are a consideration for sinonasal tract tumors. ${ }^{71,78}$

\section{Sinonasal Neuroendocrine Carcinoma}

Sinonasal neuroendocrine carcinomas are rare, highgrade tumors that must show morphologic and immunophenotypic features of neuroendocrine differentiation, separated into large and small cell types, the latter included in the differential diagnosis herein.

Clinical. Patients present in middle age (40-55 years), with men more commonly affected than women. ${ }^{52,79-81}$ A smoking ${ }^{53}$ and high-risk $\mathrm{HPV}^{82}$ association are rare. Symptoms are non-specific, with tumors involving the ethmoid sinus, followed by nasal cavity and maxillary sinus, with advanced local disease 

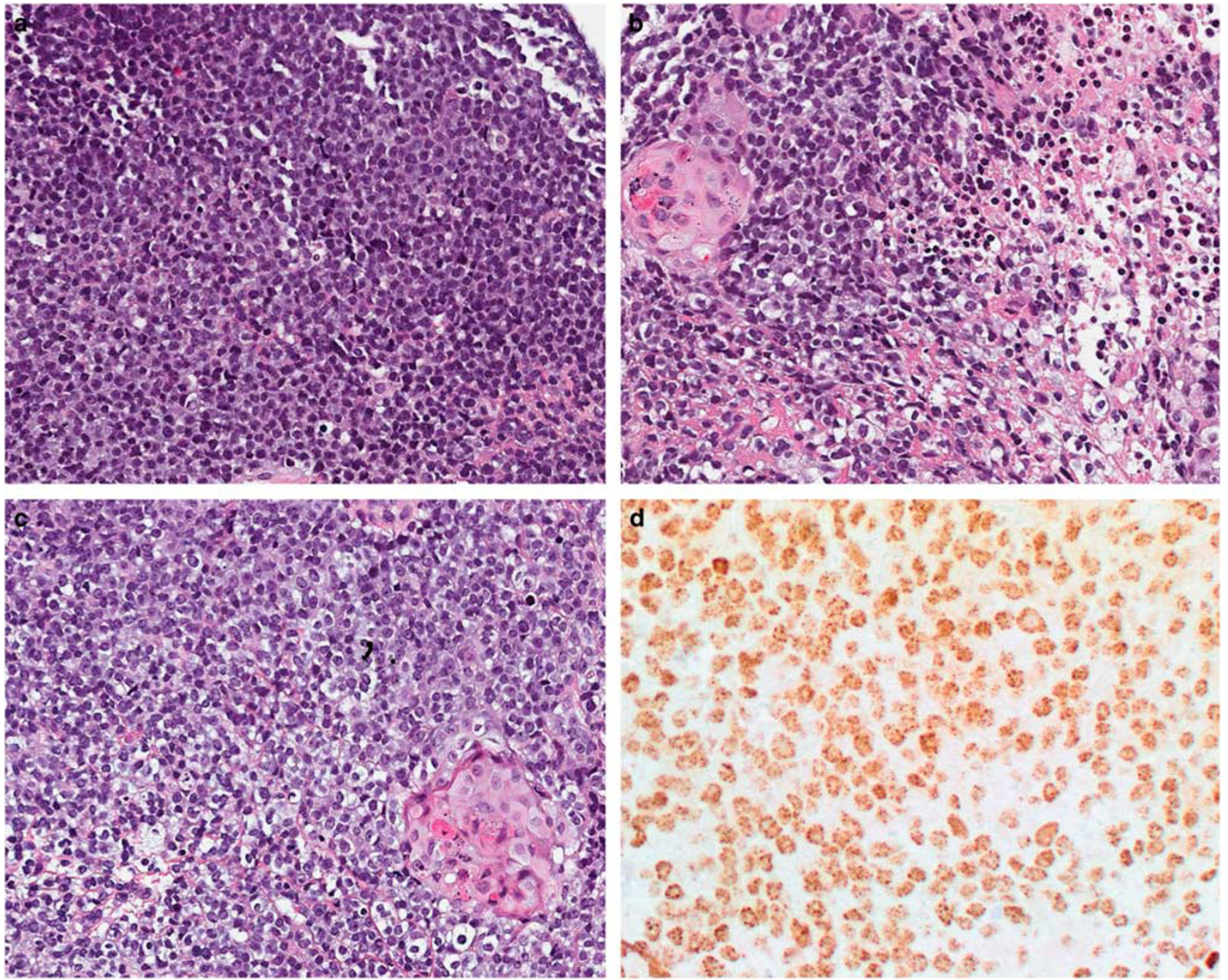

Figure 7 NUT carcinoma. Undifferentiated, small round blue cells (a), often associated with necrosis and areas of abrupt squamous differentiation (pearl formation; b,c). There is a strong nuclear punctate reaction with NUT immunohistochemistry (d).

(pT3 or T4) and regional or distant metastases at presentation common. ${ }^{52,53,80,83,84}$

Histopathology. In general, the tumors are clinically large and destructive, frequently accompanied by tumor necrosis (Figure 8), showing bone destruction, perineural invasion, and lymphovascular invasion. ${ }^{52,80,85}$ The tumors grow in multiple patterns, including sheets, nests, lobules (Figure 8), ribbons, festoons, and trabeculae, occasionally showing rosettes or palisading. The cells are small to medium, with nuclear molding, apoptosis, prominent crush artifact, and cannibalism, with a high mitotic index ( $>10 / 10$ high power fields) including atypical forms. The cells may be round, polygonal to spindled, with cytoplasm that is generally scant, but ranges from granular, eosinophilic to amphophilic. Nuclear neuroendocrine features must be present, and include salt-and-pepper clumped nuclear chromatin without prominent nucleoli (Figures 8 and 9). Rarely, small cell carcinoma may be combined with a squamous cell carcinoma or adenocarcinoma, ${ }^{86,87}$ but neuroendocrine histologic features must be present rather than just detected by immunohistochemistry.

Special studies. Small cell neuroendocrine carcinomas are usually strongly and diffusely reactive with cytokeratins (AE1/AE3, CAM5.2) and EMA, often in a perinuclear dot-like reaction (Figure 9). At least one neuroendocrine marker (synaptophysin [Figure 9c], chromogranin, NSE, CD56) must be positive ${ }^{64,80,84,88,89}$ Rarely, S100 protein may be positive, but it is diffuse rather than sustentacular. ${ }^{52}$ p16 is strongly expressed, TTF-1 may be seen (Figure 9d), whereas p63 and calretinin may show rare, focal reactivity. ${ }^{57,88}$

Outcome and management. Tumors are managed by multimodality combination of surgery and chemoradiation, yielding an overall 5-year disease-free 

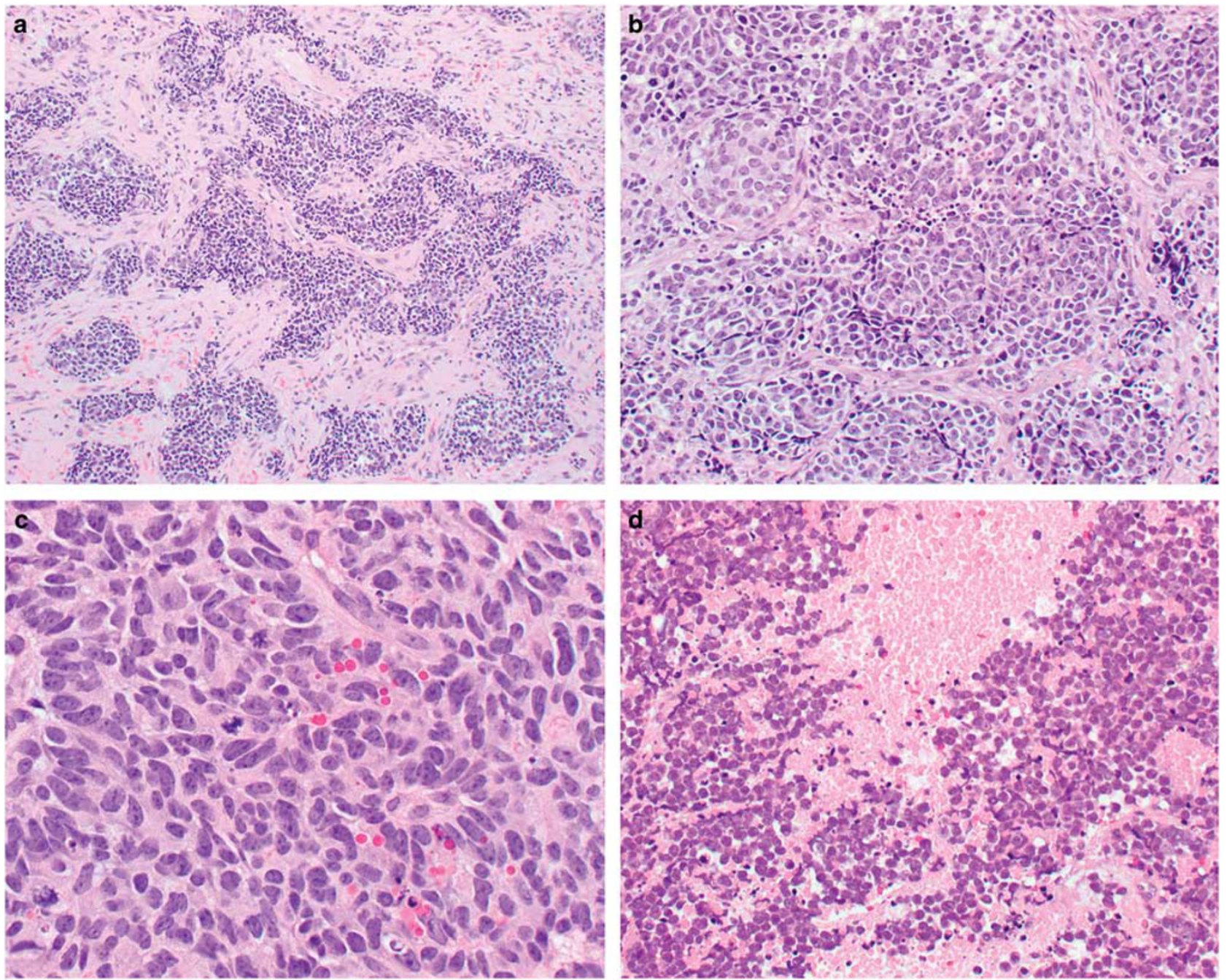

Figure 8 Sinonasal neuroendocrine carcinoma. A sheet-like to nested appearance (a) is composed of small cells that are molded to one another, with apoptosis (b). There is a delicate, salt-and-pepper nuclear chromatin (c) even when the tumor cells show slight elongation. Mitoses are easily identified. Tumor necrosis is frequent (d).

survival of about $50-65 \%$, often better for sphenoid sinus $(\sim 80 \%)$ rather than maxillary or ethmoid sinus $(\sim 33 \%)$ tumors. ${ }^{64,79,80,84,90}$

\section{Small Cell Osteosarcoma}

Osteosarcomas are defined as malignant tumors whose cells produce bone, but are very rare in the sinonasal tract.

Clinical. Sinonasal tract osteosarcomas affect the sexes equally, but develop about 10-20 years later than appendicular counterparts. ${ }^{91,92}$ The majority are spontaneous, but post-radiation and Paget disease of bone are etiologic agents. ${ }^{93,94}$ Bone destruction by a mixed radiolucent-radio-opaque mass helps define the extent of disease radiographically. ${ }^{91,94}$

Histopathology. Neoplastic osteoid produced by highly atypical osteocytes is required for the diagnosis. Bone remodeling and destruction at the periphery of the tumor is not bone production. The bone matrix varies from focal to diffuse, showing immature lace-like osteoid to more sclerotic and mineralized bone. In the context of a small round blue cell tumor, the neoplastic cells are anaplastic and pleomorphic polygonal to epithelioid cells set within the bony matrix. Mitoses and necrosis may be seen. Associated cartilage, fibroblastic cells, and irregular bony trabeculae may be seen in other variants of osteosarcoma. Importantly, when cartilage is found, a chondroblastic osteosarcoma is more common in the sinonasal tract than primary chondrosarcoma, thus a diligent search for malignant bone is recommended.

Special studies. Osteosarcoma generally lack reactivity with other markers in the differential diagnostic considerations of a small round blue cell tumor, 

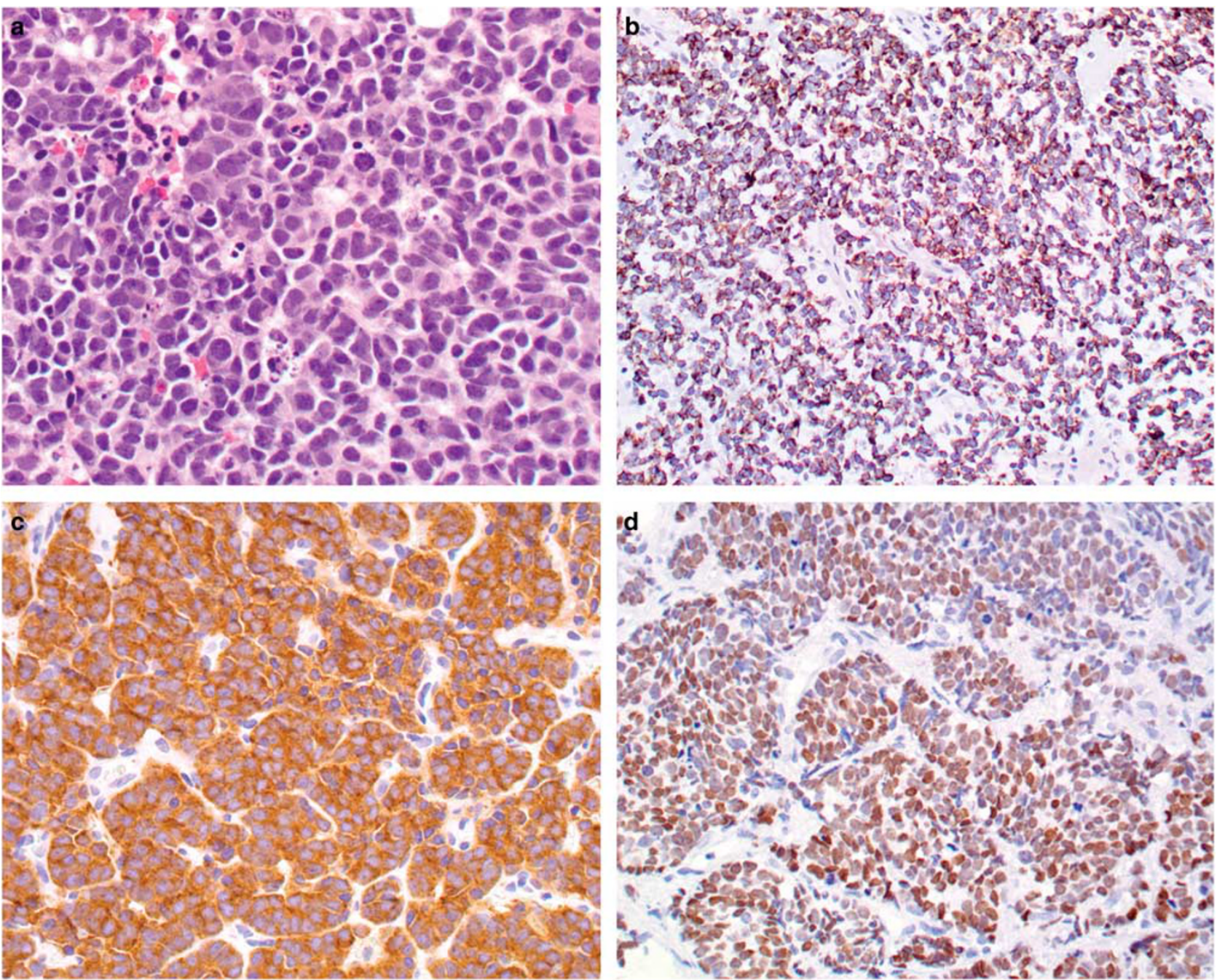

Figure 9 Sinonasal neuroendocrine carcinoma. Neoplastic cells with a high nuclear to cytoplasmic ratio, scant cytoplasm, molding and delicate nuclear chromatin (a) are characteristic. A dot-like cytoplasmic pancytokeratin (b) reaction, whereas synaptophysin (c) shows a strong cytoplasmic reaction. TTF-1 (d) may be expressed in primary sinonasal tract neuroendocrine carcinomas.

but MDM2, CDK4, and osteonectin may help in difficult cases. ${ }^{95,96}$

Outcome and management. Osteosarcomas of the sinonasal tract must be resected with clear margins if a good outcome is to be expected, but difficult to achieve in this site, with chemotherapy frequently employed..$^{97,98}$

\section{Lymphoma or Plasmacytoma}

Extranodal natural killer (NK)/T-cell lymphoma, nasal type is a lymphoma with a cytotoxic phenotype, universally associated with Epstein-Barr virus (EBV), whereas extra osseous plasmacytoma is a massforming proliferation of monoclonal plasma cells without underlying multiple myeloma. A complete discussion of hematolymphoid diseases is discussed elsewhere in this issue ${ }^{99}$ with only a few pertinent points presented here.
Clinical. Extranodal NK/T-cell lymphoma, nasal type, is pathogenetically related to EBV, showing a complex geographic and racial increased prevalence in East Asians and indigenous peoples of Mexico, Central and South America. ${ }^{100-103}$ Tumors most commonly present with obstruction and central destruction or perforation of the nasal cavity and paranasal sinuses, ${ }^{104-106}$ most patients presenting with low stage I or II disease.

Histopathology. NK/T-cell lymphoma, nasal type shows an arc of development clinically, with a similar arc histologically. In the beginning there is a mixed B- and T-cell population, including eosinophils, histiocytes, and mast cells. However, with time, there is a diffuse infiltrate, showing an angiocentric and angiodestructive growth with geographictype tumor necrosis (Figure 10). The neoplastic cells are dyscohesive, of variable size and shape, often showing nuclear folds and grooves, with coarse 

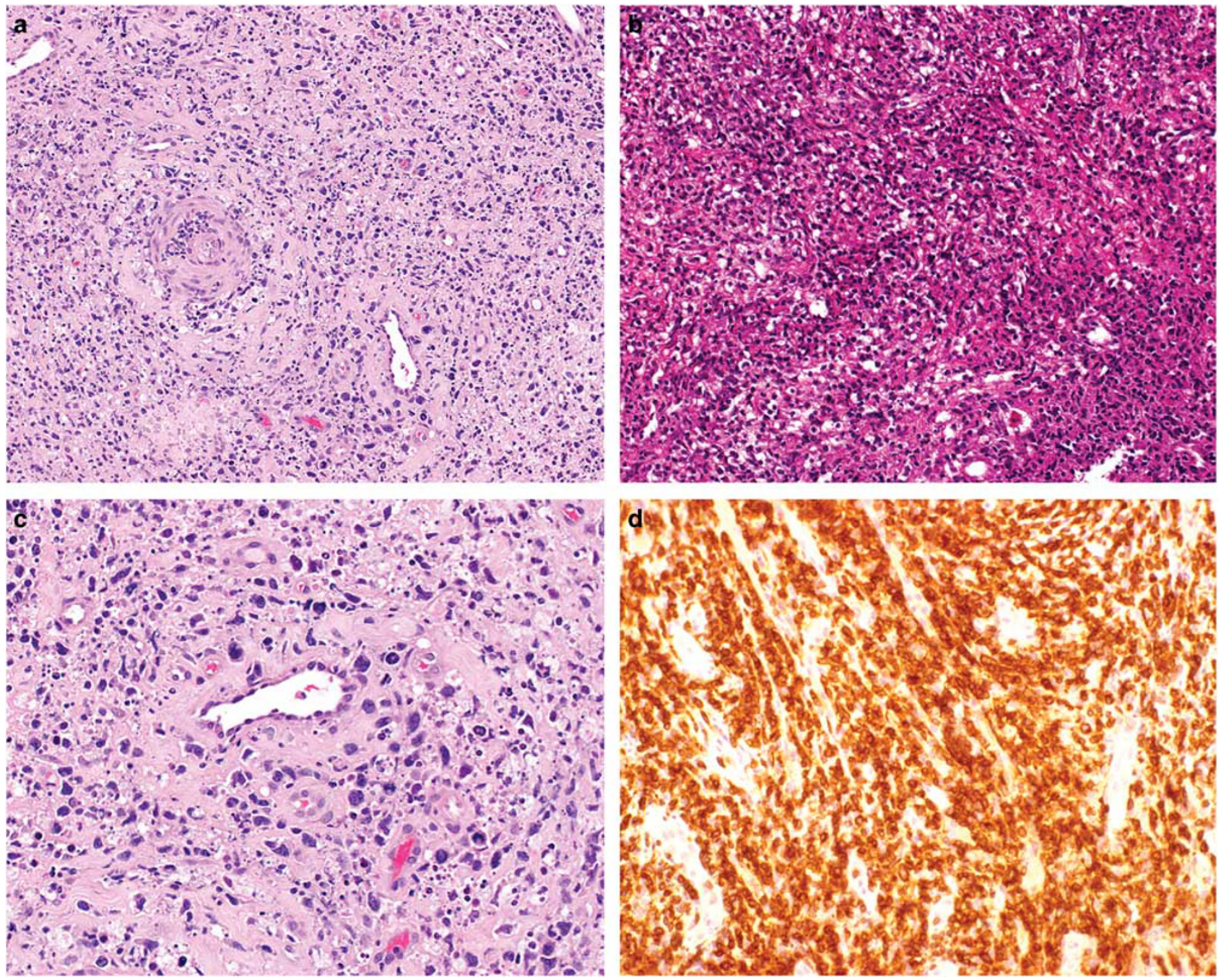

Figure 10 NK/T-cell lymphoma, nasal type. An angiocentric and angioinvasive pattern is characteristic (a). A sheet-like distribution of atypical dyscohesive cells may be seen (b). The vessel wall is infiltrated by highly atypical lymphocytes (c). The neoplastic cells are strongly reactive with CD3e (d).

irregular nuclear chromatin distribution. A surface pseudoepitheliomatous hyperplasia may obscure the true nature of the neoplastic proliferation.

By contrast, plasmacytoma shows a diffuse, sheetlike infiltration of well to poorly differentiated plasma cells, ${ }^{107,108}$ showing the characteristic clock-face chromatin distribution and eccentric cytoplasm. Cytoplasmic immunoglobulins, Mott cells, and nuclear Dutcher bodies may help with diagnosis, while extracellular amyloid is occasionally present. ${ }^{109}$ MALT-type lymphomas with extensive plasmacytic differentiation may be seen.

Special studies. The neoplastic cells are reactive with CD45RB, cytoplasmic CD3, cytotoxic markers, (TIA-1, granzyme B, perforin), and quite commonly CD56. ${ }^{104,105,110,111}$ Although most are NK-cells, T-cell lineage tumors may also be seen with CD5 reactivity. The neoplastic cells are uniformly positive with EBER by in situ hybridization (EBV LMP1 should not be tested); ${ }^{12,113}$ negative cases are considered peripheral T-cell lymphoma. ${ }^{114,115}$ CD57, muscle markers and epithelial markers are non-reactive.

Plasmacytic markers including CD138, CD38 ${ }^{116}$ and CD79a are usually seen, with rare CD20 coexpression. EMA may be positive. PAX5 is negative. Monotypic immunoglobulin light chains are usually demonstrated by immunohistochemistry or in situ hybridization.

Outcome and management. Stage, surrogately detected by circulating EBV DNA plasma levels is of prognostic significance, ${ }^{117-119}$ with chemoradiation regimens achieving $70-80 \%$ 5-year survival rates. ${ }^{118,120}$ The outcome for plasmacytoma is better than multiple myeloma, with patients managed by localized radiation. ${ }^{108,121}$ 

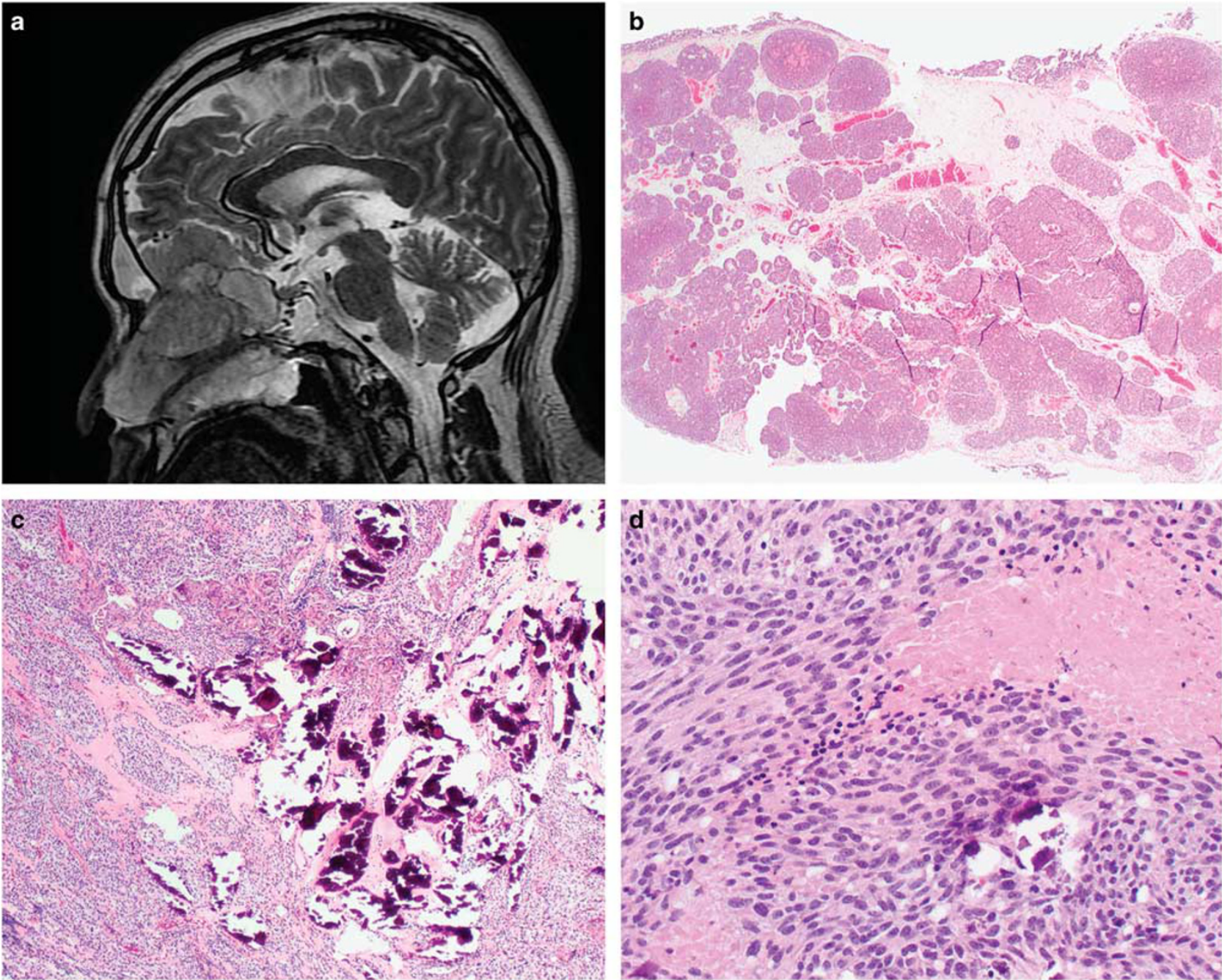

Figure 11 Olfactory neuroblastoma. Enhancement is noted within a large nasal cavity and intracranial mass on T2-weighted MRI (a). A lobular architecture is nearly always present (b). Calcifications may be seen (c). Tumor necrosis (d) and increased mitoses are generally seen in higher grade tumors.

\section{Olfactory Neuroblastoma (Esthesioneuroblastoma)}

Olfactory neuroblastoma is a malignant neuroectodermal tumor with neuroblastic differentiation, most often localized to the superior nasal cavity and ethmoid sinus, accounting for about $3 \%$ of all sinonasal tract tumors. ${ }^{122-125}$

Clinical. Patients of all ages are affected, with a peak in the 5th-6th decades, with males slightly more often affected than females $(1.2: 1){ }^{126,127}$ Symptoms are non-specific; anosmia and paraneoplastic syndromes are rare. ${ }^{128}$ Biopsy is discouraged due to high vascularity. MRI preferentially highlights intraorbital or base of skull extension showing avid enhancement with contrast of a dumbbellshaped mass, the waist at the cribriform plate (Figure 11). Tumor cysts and speckled calcifications are commonly seen on computed tomography
Table 3 Olfactory neuroblastoma grading

\begin{tabular}{lcccc}
\hline Feature & Grade 1 & Grade 2 & Grade 3 & Grade 4 \\
\hline Architecture & L & L & L & L \\
Mitoses & - & + & ++ & +++ \\
Anaplasia & - & + & ++ & +++ \\
Matrix & ++ & + & $+/-$ & - \\
Rosettes & HW & HW & FW & FW \\
Necrosis & - & - & \pm & + \\
\hline
\end{tabular}

Abbreviations: L, lobular; FW, Flexner-Wintersteiner rosettes; HW, Homer Wright rosettes.

(but may be seen histologically also; Figure 11). The ethmoid sinus, superior turbinate, and upper half of the nasal septum are the sites of predilection, with ectopic locations diagnoses of exclusion only. ${ }^{124,129}$ Expansion into adjacent sinuses or 

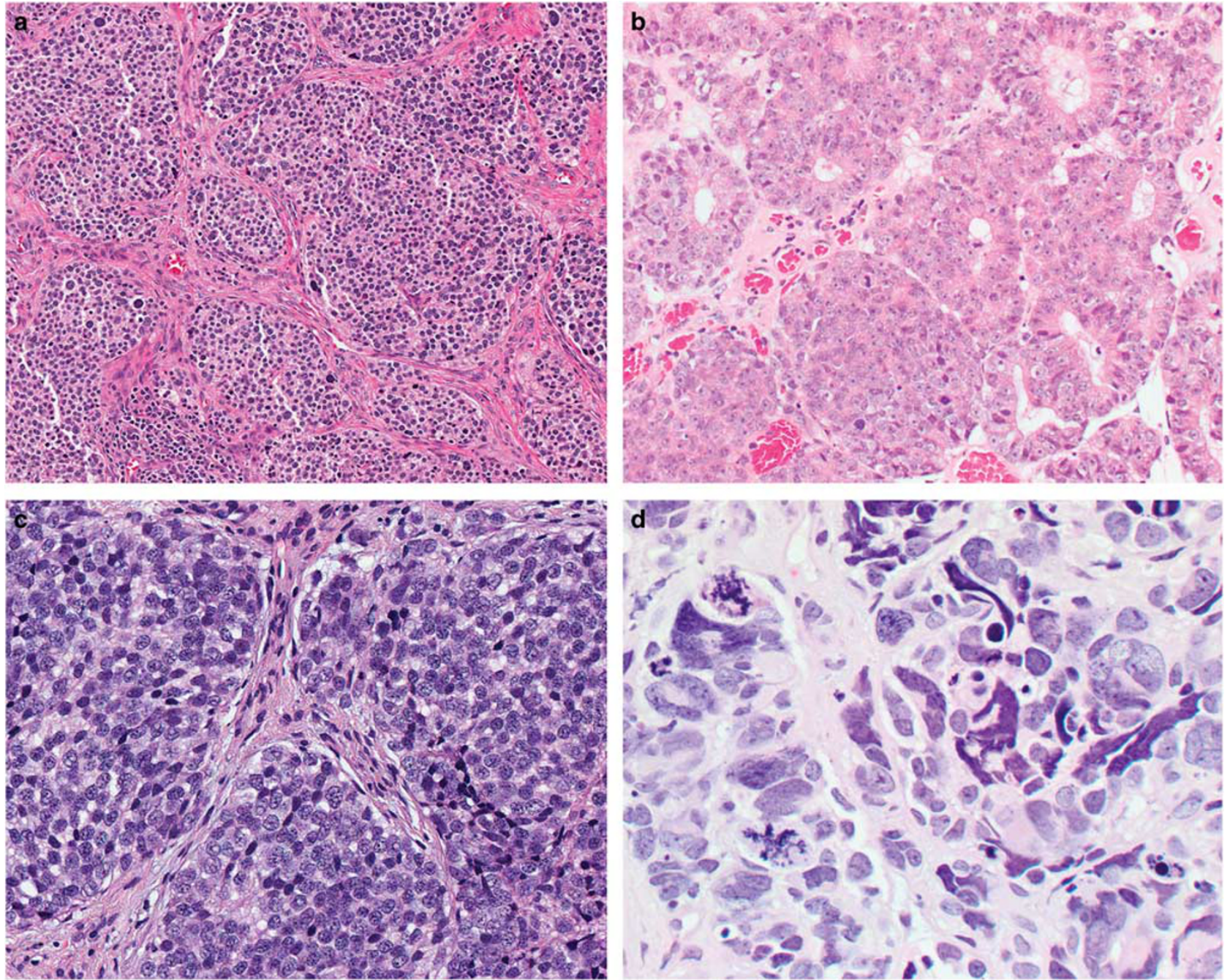

Figure 12 Olfactory neuroblastoma. The lobules of tumor are separated by a rich fibrovascular stroma (a). There are true rosettes noted in this tumor with prominent nucleoli (b). The nuclei are slightly larger than lymphocytes and show a slightly increased nuclear to cytoplasmic ratio in this grade 2 tumor (c). Profound pleomorphism and atypical mitoses (d) are characteristic of a grade 4 tumor.

base of the skull and brain help define tumor stage, with the Kadish system most commonly employed. ${ }^{130-132}$

Histopathology. Often polypoid, there is usually an intact surface mucosa; rarely, an in situ component will be identified in the olfactory epithelium. No matter the tumor grade, the tumor cells are arranged in variably sized lobules to sharply demarcated nests, separated by a vascularized to fibrous connective tissue stroma (Figures 11 and 12). The tumor grade determines the histologic appearance, with low-grade tumors being the classical finding (Table 3). The tumor cells are small and uniform (about the size of lymphocytes), with scant cytoplasm surrounding round and regular nuclei with slightly hyperchromatic, delicate, punctate, salt-andpepper nuclear chromatin (Figure 12). Nucleoli are inconspicuous. The cells appear syncytial, often showing neuropil or neural tangles, which occasionally create Homer Wright pseudorosettes (Figure 11) when the nuclei cuff or palisade around the fibrillar matrix. As the tumor grade increases, tumor necrosis (Figure 11), increased mitoses (Figure 12), pleomorphism (Figure 12), and true Flexner-Wintersteiner rosettes may be seen (tight annular structures with lumen and possible secretions; Figure 12). The grade (Table 3 ) is related to the degree of maturation, amount of neuropil, mitoses, necrosis, and pleomorphism, ${ }^{133}$ and is strongly correlated to outcome. ${ }^{130,132,134-138}$ Although rare, melanin pigment, ganglion cells, rhabdomyoblasts, and even squamous or glandular differentiation may be seen. ${ }^{124,139-141}$

Special studies. The neoplastic cells will be reactive with neuroendocrine markers (synaptophysin, chromogranin-A, neuron specific enolase, CD56), 

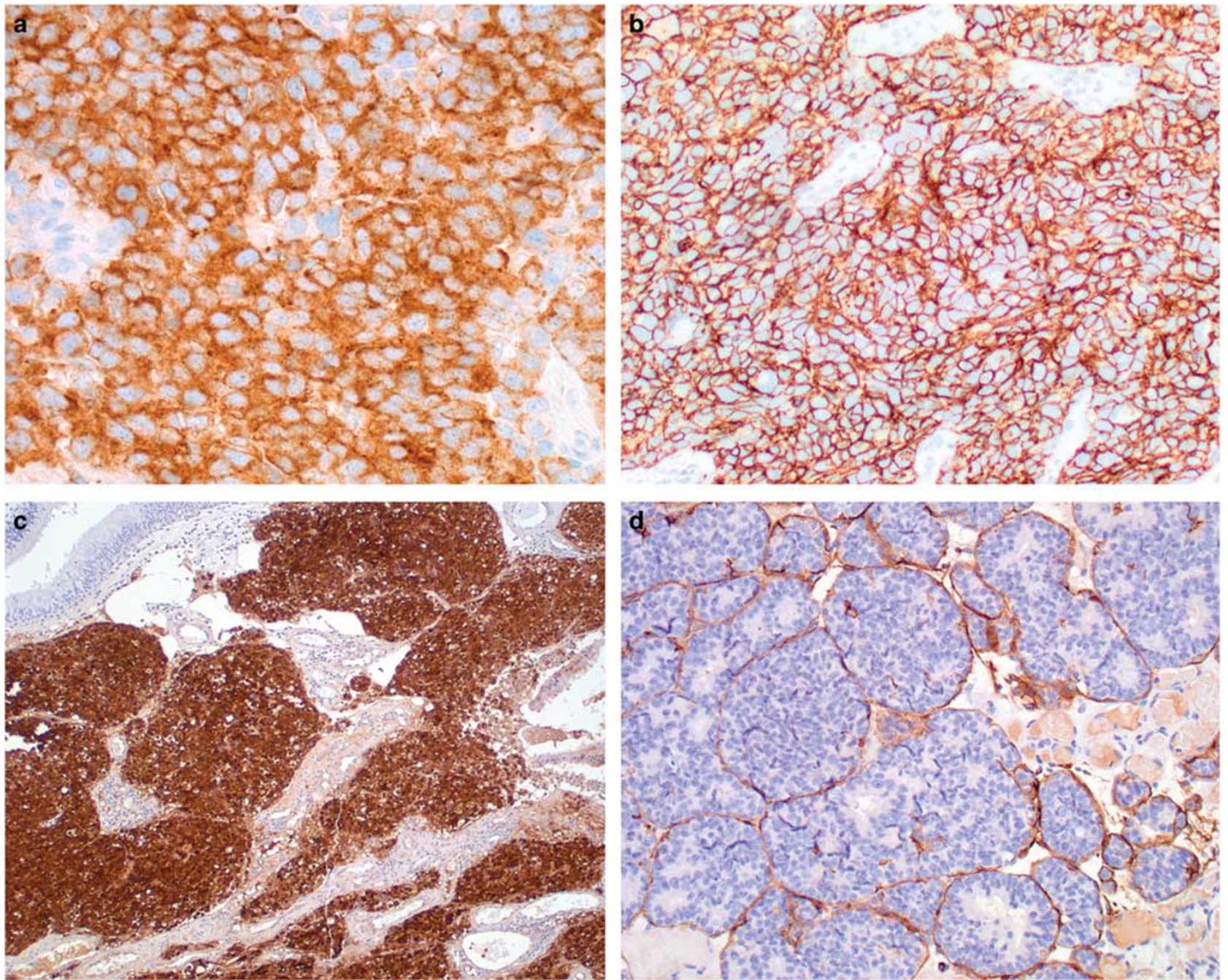

Figure 13 Olfactory neuroblastoma. The neoplastic cells show a strong and diffuse reaction with synaptophysin (a), CD56 (membrane b), and calretinin (c). There is a delicate, supporting sustentacular reaction with S100 protein at the periphery of the lobules (d).

along with calretinin (nuclear and cytoplasmic); S100 protein and/or GFAP highlights the sustentacular supporting cells at the periphery of the tumor lobules (Figure 13). CAM5.2, CK18 or pancytokeratin may be focally expressed in some olfactory neuroblastoma; desmin or myogenin may be seen in tumors with rhabdomyoblastic differentiation. Negative markers include CD45RB, CD99, p63, and FLI-1. ${ }^{4,57,80,140,142-146}$

Outcome and management. Using a predominantly surgical approach, combined with radiation and chemotherapy in certain settings, the tumor grade and stage are the most significant prognostic factors, ${ }^{130,132,134-138}$ with metastatic tumors showing a worse disease-free survival. Recurrences usually develop within 2 years, seen in up to $30 \%$ of patients, whereas distant metastases are uncommon (about 10\%).

\section{Ewing Sarcoma/Primitive Neuroectodermal Tumor}

Ewing sarcoma/primitive neuroectodermal tumor is a high-grade primitive small round cell sarcoma with neuroectodermal differentiation defined by the presence of an EWSR1 gene translocation. Up to $10 \%$ develop in the head and neck. ${ }^{147}$

Clinical. Tumors develop slightly more often in males, most commonly in young patients, but older patients may be affected. ${ }^{148-150}$ The skull and jaws are much more commonly affected than the sinonasal tract. ${ }^{150}$ Symptoms are non-specific, but tend to develop rapidly, with imaging studies showing orbital or intracranial extension.

Histopathology. Polypoid tumors frequently display ulceration, with bone invasion noted. The tumors show high cellularity arranged in a diffuse, 

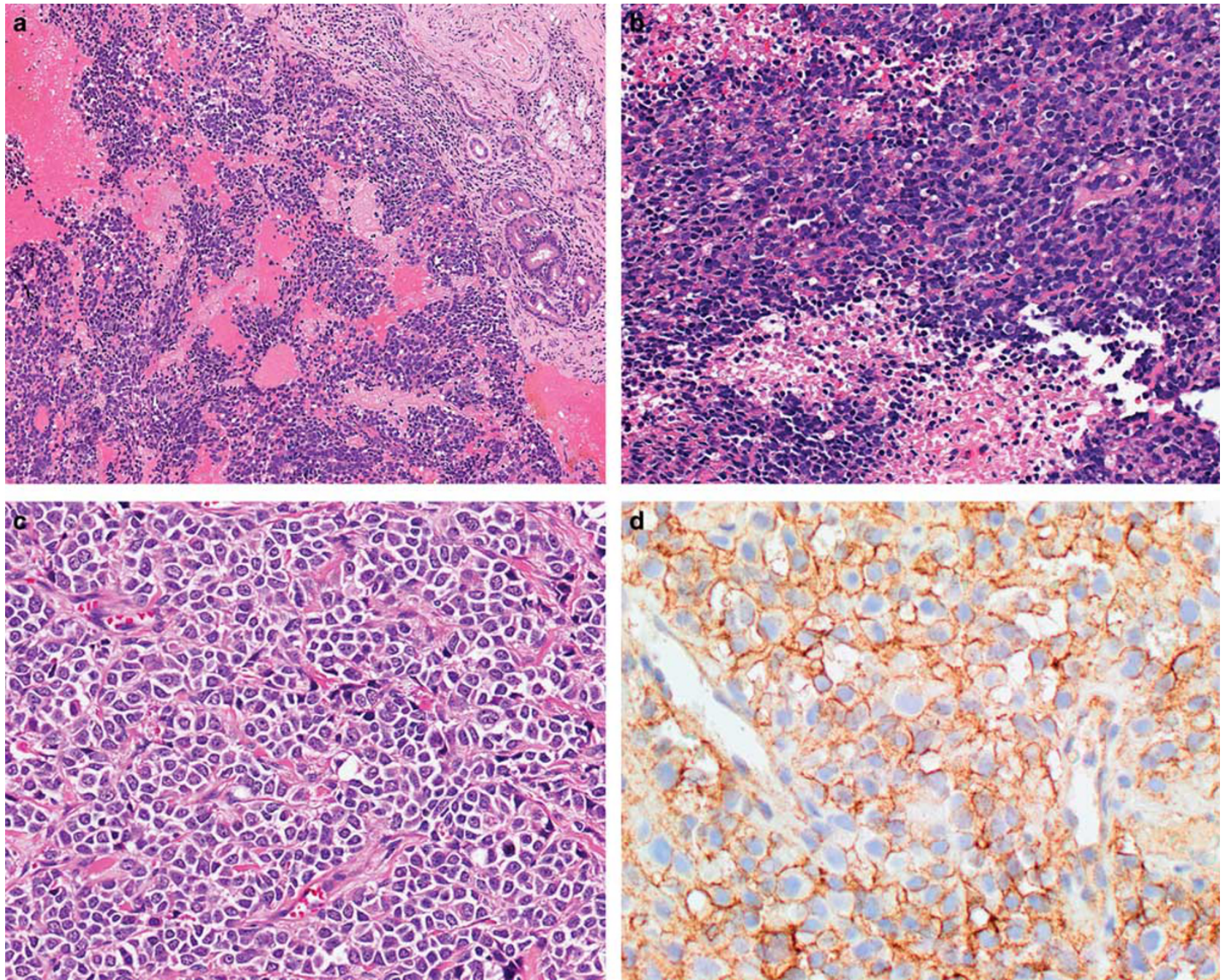

Figure 14 Ewing sarcoma. There is tumor necrosis and a sheet-like distribution (a) of the neoplastic cells. Comedonecrosis (b) is seen; the cells have scant cytoplasm. There cells may have a more coarse nuclear chromatin (c) and high nuclear to cytoplasmic ratio. The neoplastic cells show a strong, membranous, and cytoplasm reaction with CD99 (d).

sheet-like to lobular appearance. Necrosis is usually easily identified with limited vascular stroma (Figure 14). Mitoses are usually easily identified. The neoplastic cells are small and uniform, with scant pale to cleared cytoplasm surrounding round to oval nuclei with powdery to finely clumped chromatin, and small, inconspicuous nucleoli. Pseudorosettes may be present, but true neural rosettes are rare. In the sinonasal tract, the adamantinomalike variant may be seen. ${ }^{151,152}$

Special studies. Glycogen may be demonstrated by diastase-sensitive, PAS-positive material. A strong and diffusive membranous CD99 reactivity (Figure 14) is the most sensitive marker for this tumor; nuclear FLI1 and ERG are also commonly identified, but are not specific. ${ }^{6,50,81,153,154}$ Importantly, pancytokeratin may be expressed in a dot-like pattern (up to $30 \%$ of cases), but more often in adamantinoma-like tumors; ${ }^{150,152,155}$ p63 is infrequently identified; ${ }^{57}$ neural markers may be seen (NSE, S100 protein, synaptophysin, chromogranin); CD117 is uncommon, and desmin is rarely coexpressed. A FISH EWSR1 break-apart probe helps to identify the class of tumor, although it does not confirm the translocation partner (which is usually FLL1). CIC-DUX4 fusions may be seen in EWSR1-negative cases, ${ }^{156}$ although controversial. ${ }^{157}$

Outcome and management. The 50-75\% 5-year survival for sinonasal Ewing sarcoma is much better than other sites, but local recurrence and metastases, when they develop are usually soon (2 years) after initial presentation. ${ }^{147,150}$ Tumors are managed with multimodality therapy, but there is a risk of posttreatment sarcoma development. Poor prognosis may be related to p53 aberrations. ${ }^{158}$ 

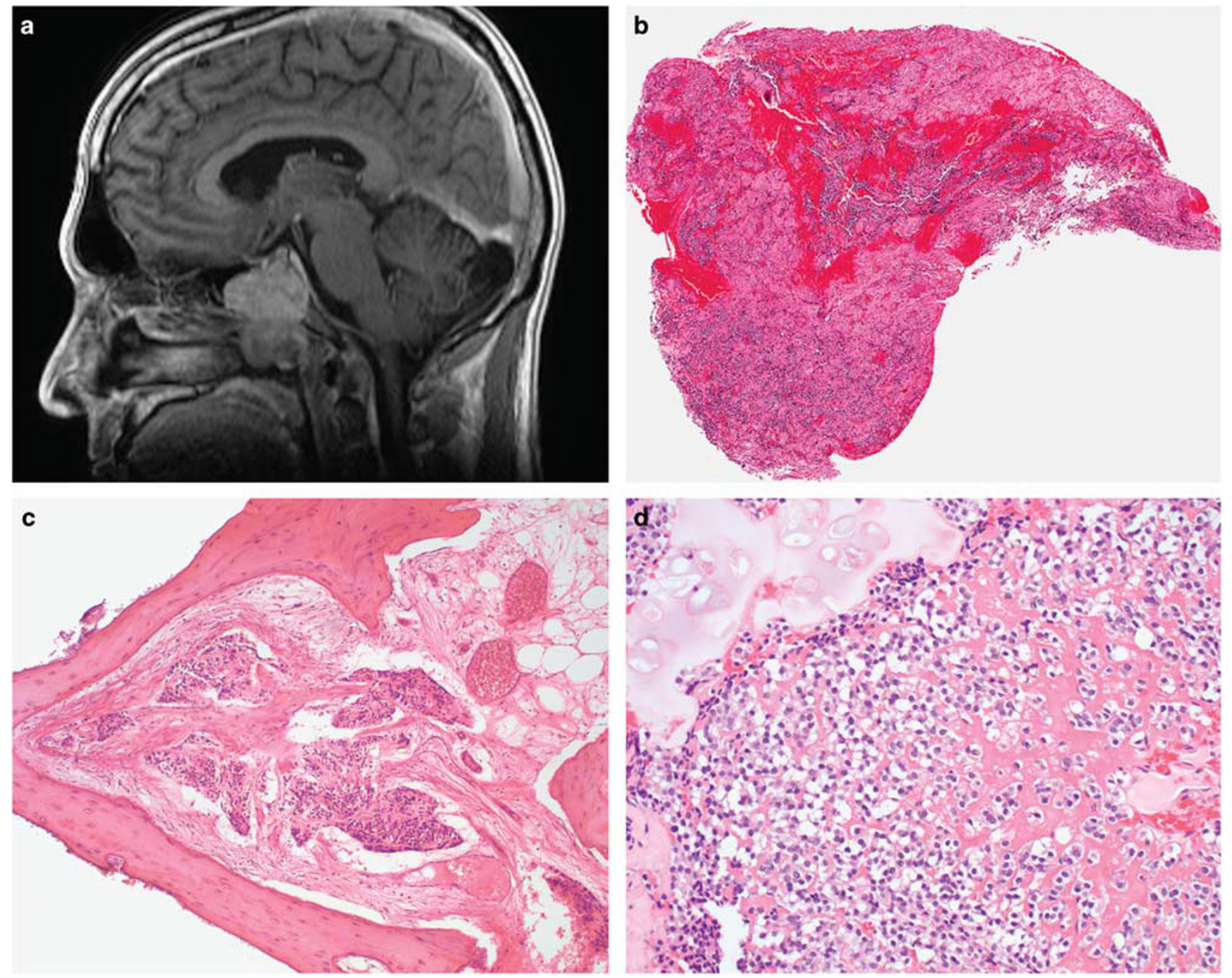

Figure 15 Pituitary adenoma. This sagittal MRI shows a large mass within the pituitary sella and expanding into the sphenoid sinus (a). The tumors often appear polypoid (b). Bone invasion (c) may be seen, while cartilage invasion (d) may also be present. This is not neoplastic cartilage or bone, but destruction of the native structures.

\section{Pituitary Adenoma}

Whether ectopic (remnants of Rathke pouch) or by direct extension from the sella, pituitary adenoma may involve the sphenoid sinus and sinonasal tract. Direct extension is more common than ectopic tumors, comprising $<3 \%$ of all tumors in this site. ${ }^{159-161}$

Clinical. Patients present over a wide age range, but show a mean presentation in the mid-50s, females affected slightly more often than males (1.3:1). Sphenoid sinus and nasopharynx are the most commonly affected sites. ${ }^{159}$ Symptoms are nonspecific, although visual disturbances are more common with sella involvement, whereas endocrinopathies are infrequent, ${ }^{162}$ and about $10 \%$ of patients are asymptomatic. Imaging studies are generally encouraged to exclude direct extension (Figure 15), where bone destruction is present. ${ }^{159,163}$
Histopathology. The frequently polypoid tumors can be quite sizeable $(8 \mathrm{~cm})$, often associated with bone invasion and necrosis (Figure 15). ${ }^{159,164}$ The submucosal tumors show a variety of growth patterns, with a solid, organoid, and trabecular growth patterns most common, but hypocellular, heavily collagenized tumors may be seen (Figure 16). Rosettes and pseudorosettes may be present. The cells range from polygonal, epithelioid to plasmacytoid, generally with round nuclei and salt-andpepper nuclear chromatin, often with intranuclear cytoplasmic inclusions. Glandular spaces may be seen with secretions (Figures 16 and 17). Profound pleomorphism in isolation is part of an endocrine organ neoplasm. Squamous differentiation is not appreciated. Mitoses can be found, but atypical forms are not present. Lymphovascular and perineural invasion are not seen. ${ }^{159,165}$ 

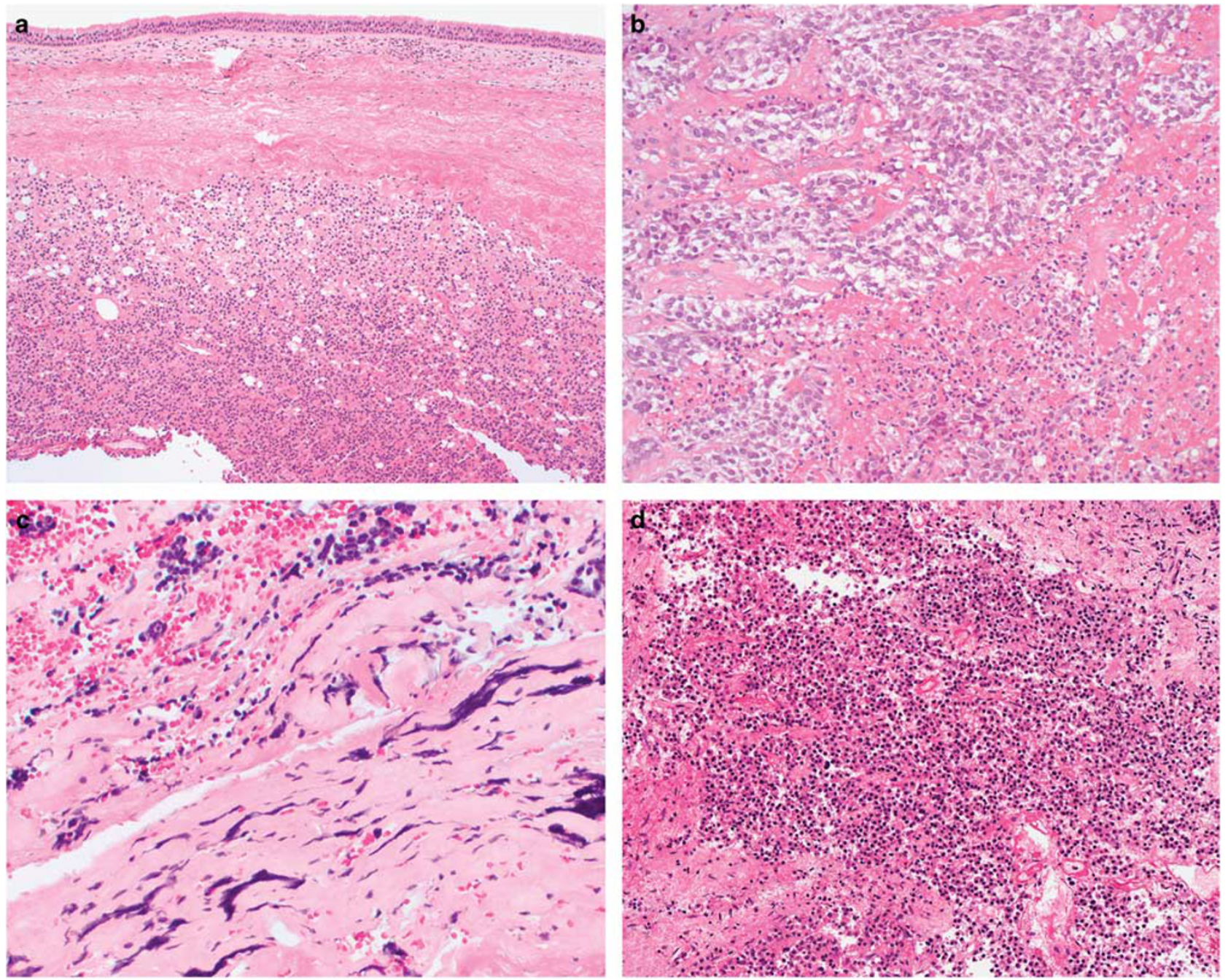

Figure 16 Pituitary adenoma. There is separation from the intact surface epithelium (a). Tumor necrosis may be seen. This tumor has a lobular or trabecular growth (b). Dense fibrous stroma may obscure the neoplastic cells and compress them (c). There is usually a rich fibrovascular stroma in neuroendocrine tumors (d).

Special studies. The neoplastic cells show neuroendocrine and epithelial markers (Figure 17b), with synaptophysin (Figure 17c) more commonly expressed than chromogranin or NSE. CK-pan is seen in about $80 \%$ (Figure 17b), often with a perinuclear dot-like pattern. Prolactin $(\sim 60 \%)$ is one of the most common pituitary hormones expressed (Figure 17d), but any pituitary hormone or transcription factor (Pit-1, T-pit, SF-1) may be expressed (single or multiple hormones/factors). ${ }^{159,164}$

Outcome and management. Medical management (such as bromocriptine), surgery or radiation (unresectable tumors) may be employed with pituitary adenomas, with recurrences noted in incompletely removed tumors.

\section{Conclusion}

It is important to think broadly about epithelial, mesenchymal, neuroendocrine, and lymphoid tumors within the sinonasal tract small round blue cell tumor group. The mnemonic of MR SLEEP can help to focus the differential diagnostic considerations, keeping in mind the exact and specific anatomic site, imaging findings, and combining the histologic features with pertinent positive and negative immunohistochemistry findings, using additional molecular results as necessary to confirm the diagnosis. There will be significant histological and immunohistochemistry overlapping, but when combined with the site of origin, imaging findings, and other clinical findings, the correct result can be achieved. 

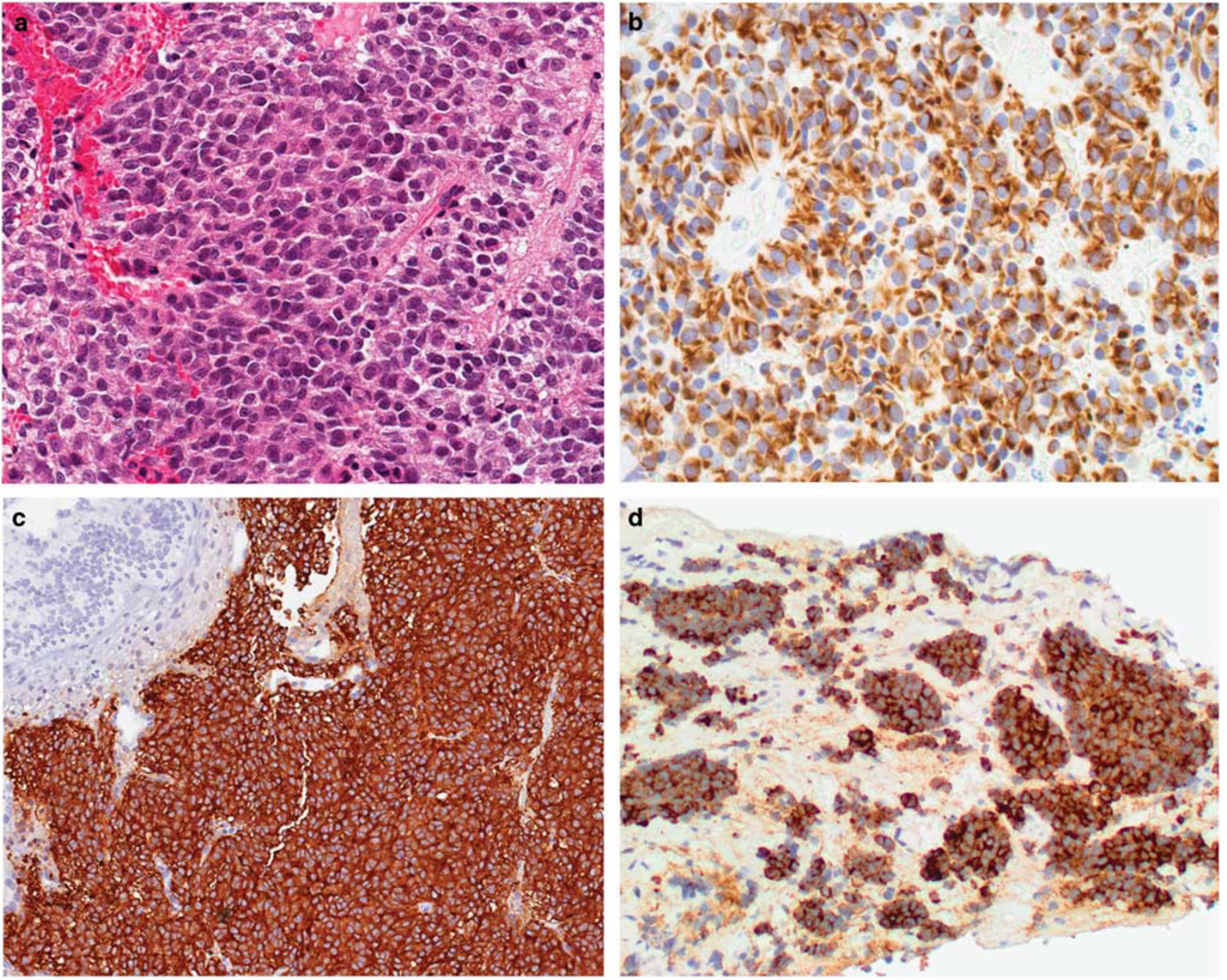

Figure 17 Pituitary adenoma. The neoplastic cells are small, showing delicate-fine to coarse nuclear chromatin (a). The neoplastic cells show a characteristic paranuclear dot-like reaction with pancytokeratin (b), strong cytoplasmic reaction with synaptophysin (c), and a diffuse reaction with prolactin (d).

\section{Acknowledgments}

A special thanks to Ms Hannah B Herrera for her research assistance. The opinions or assertions contained herein are the private views of the author and are not to be construed as official or as reflecting the views of the Southern California Permanente Medical Group.

\section{Disclosure/conflict of interest}

The author declares no conflict of interest.

\section{References}

1 Magro G, Longo FR, Angelico G et al. Immunohistochemistry as potential diagnostic pitfall in the most common solid tumors of children and adolescents. Acta Histochem 2015;117:397-414.
2 Antonescu C. Round cell sarcomas beyond Ewing: emerging entities. Histopathology 2014;64:26-37.

3 Bridge JA, Bowen JM, Smith RB. The small round blue cell tumors of the sinonasal area. Head Neck Pathol 2010;4:84-93.

4 Iezzoni JC, Mills SE. 'Undifferentiated' small round cell tumors of the sinonasal tract: differential diagnosis update. Am J Clin Pathol 2005;124 Suppl: S110-S121.

5 Devaney K, Wenig BM, Abbondanzo SL. Olfactory neuroblastoma and other round cell lesions of the sinonasal region. Mod Pathol 1996;9:658-663.

6 Wenig BM. Undifferentiated malignant neoplasms of the sinonasal tract. Arch Pathol Lab Med 2009;133: 699-712.

7 Thompson LD, Wieneke JA, Miettinen M. Sinonasal tract and nasopharyngeal melanomas: a clinicopathologic study of 115 cases with a proposed staging system. Am J Surg Pathol 2003;27:594-611.

8 Gal TJ, Silver N, Huang B. Demographics and treatment trends in sinonasal mucosal melanoma. Laryngoscope 2011;121:2026-2033. 
9 Lazarev S, Gupta V, Hu K et al. Mucosal melanoma of the head and neck: a systematic review of the literature. Int J Radiat Oncol Biol Phys 2014;90:1108-1118.

10 Moreno MA, Roberts DB, Kupferman ME et al. Mucosal melanoma of the nose and paranasal sinuses, a contemporary experience from the M. D. Anderson Cancer Center. Cancer 2010;116:2215-2223.

11 Prasad ML, Jungbluth AA, Iversen K et al. Expression of melanocytic differentiation markers in malignant melanomas of the oral and sinonasal mucosa. Am J Surg Pathol 2001;25:782-787.

12 Lee H, Torres FX, McLean SA et al. Immunophenotypic heterogeneity of primary sinonasal melanoma with aberrant expression of neuroendocrine markers and calponin. Appl Immunohistochem Mol Morphol 2011;19:48-53.

13 Cancer Genome Atlas Network. Genomic Classification of Cutaneous Melanoma. Cell 2015;161: 1681-1696.

14 Zebary A, Jangard M, Omholt K et al. KIT, NRAS and BRAF mutations in sinonasal mucosal melanoma: a study of 56 cases. Br J Cancer 2013;109:559-564.

15 Turri-Zanoni M, Medicina D, Lombardi D et al. Sinonasal mucosal melanoma: molecular profile and therapeutic implications from a series of 32 cases. Head Neck 2013;35:1066-1077.

16 Lund VJ, Chisholm EJ, Howard DJ, Wei WI. Sinonasal malignant melanoma: an analysis of 115 cases assessing outcomes of surgery, postoperative radiotherapy and endoscopic resection. Rhinology 2012; 50:203-210.

17 Dauer EH, Lewis JE, Rohlinger AL et al. Sinonasal melanoma: a clinicopathologic review of 61 cases. Otolaryngol Head Neck Surg 2008;138:347-352.

18 Bachar G, Loh KS, O'Sullivan B et al. Mucosal melanomas of the head and neck: experience of the Princess Margaret Hospital. Head Neck 2008;30: 1325-1331.

19 Nakashima Y, Unni KK, Shives TC et al. Mesenchymal chondrosarcoma of bone and soft tissue. A review of 111 cases. Cancer 1986;57:2444-2453.

20 Knott PD, Gannon FH, Thompson LD. Mesenchymal chondrosarcoma of the sinonasal tract: a clinicopathological study of 13 cases with a review of the literature. Laryngoscope 2003;113:783-790.

21 Frezza AM, Cesari M, Baumhoer D et al. Mesenchymal chondrosarcoma: prognostic factors and outcome in 113 patients. A European Musculoskeletal Oncology Society study. Eur J Cancer 2015;51: 374-381.

22 Stewart BD, Reith JD, Knapik JA, Chi AC. Boneand cartilage-forming tumors and Ewing sarcoma: an update with a gnathic emphasis. Head Neck Pathol 2014;8:454-462.

23 Wehrli BM, Huang W, De CB et al. Sox9, a master regulator of chondrogenesis, distinguishes mesenchymal chondrosarcoma from other small blue round cell tumors. Hum Pathol 2003;34:263-269.

24 Fanburg-Smith JC, Auerbach A, Marwaha JS et al. Reappraisal of mesenchymal chondrosarcoma: novel morphologic observations of the hyaline cartilage and endochondral ossification and beta-catenin, Sox9, and osteocalcin immunostaining of 22 cases. Hum Pathol 2010;41:653-662.

25 Nakayama R, Miura Y, Ogino J et al. Detection of HEY1-NCOA2 fusion by fluorescence in-situ hybridization in formalin-fixed paraffin-embedded tissues as a possible diagnostic tool for mesenchymal chondrosarcoma. Pathol Int 2012;62:823-826.

26 Nascimento AF, Fletcher CD. Spindle cell rhabdomyosarcoma in adults. Am J Surg Pathol 2005;29: 1106-1113.

$27 \mathrm{Fu}$ YS, Perzin KH. Nonepithelial tumors of the nasal cavity paranasal sinuses, and nasopharynx: a clinicopathologic study. V. Skeletal muscle tumors (rhabdomyoma and rhabdomyosarcoma). Cancer 1976;37:364-376.

28 Gerth DJ, Tashiro J, Thaller SR. Pediatric sinonasal tumors in the United States: incidence and outcomes. J Surg Res 2014;190:214-220.

29 Szablewski V, Neuville A, Terrier P et al. Adult sinonasal soft tissue sarcoma: analysis of 48 cases from the French Sarcoma Group database. Laryngoscope 2015; 125:615-623.

30 Hicks J, Flaitz C. Rhabdomyosarcoma of the head and neck in children. Oral Oncol 2002;38:450-459.

31 Parham DM, Ellison DA. Rhabdomyosarcomas in adults and children: an update. Arch Pathol Lab Med 2006;130:1454-1465.

32 Sanghvi S, Misra P, Patel NR et al. Incidence trends and long-term survival analysis of sinonasal rhabdomyosarcoma. Am J Otolaryngol 2013;34:682-689.

33 D'Orazio JA. Inherited cancer syndromes in children and young adults. J Pediatr Hematol Oncol 2010;32: 195-228.

34 Chu Y, Liu HG, Yu ZK. Patterns and incidence of sinonasal malignancy with orbital invasion. Chin Med J (Engl) 2012;125:1638-1642.

35 Callender TA, Weber RS, Janjan N et al. Rhabdomyosarcoma of the nose and paranasal sinuses in adults and children. Otolaryngol Head Neck Surg 1995;112: 252-257.

36 Bahrami A, Gown AM, Baird GS et al. Aberrant expression of epithelial and neuroendocrine markers in alveolar rhabdomyosarcoma: a potentially serious diagnostic pitfall. Mod Pathol 2008;21: 795-806.

37 Leroy X, Petit ML, Fayoux P et al. Aberrant diffuse expression of synaptophysin in a sinonasal alveolar rhabdomyosarcoma. Pathology 2007;39:275-276.

38 Yasuda T, Perry KD, Nelson $\mathrm{M}$ et al. Alveolar rhabdomyosarcoma of the head and neck region in older adults: genetic characterization and a review of the literature. Hum Pathol 2009;40:341-348.

39 Downs-Kelly E, Shehata BM, Lopez-Terrada D et al. The utility of FOXO1 fluorescence in situ hybridization (FISH) in formalin-fixed paraffin-embedded specimens in the diagnosis of alveolar rhabdomyosarcoma. Diagn Mol Pathol 2009;18:138-143.

40 Cordes B, Williams MD, Tirado Y et al. Molecular and phenotypic analysis of poorly differentiated sinonasal neoplasms: an integrated approach for early diagnosis and classification. Hum Pathol 2009;40:283-292.

41 Raney RB, Asmar L, Vassilopoulou-Sellin R et al. Late complications of therapy in 213 children with localized, nonorbital soft-tissue sarcoma of the head and neck: a descriptive report from the Intergroup Rhabdomyosarcoma Studies (IRS)-II and-III. IRS Group of the Children's Cancer Group and the Pediatric Oncology Group. Med Pediatr Oncol 1999;33:362-371.

42 Pappo AS, Meza JL, Donaldson SS et al. Treatment of localized nonorbital, nonparameningeal head and neck rhabdomyosarcoma: lessons learned from 
intergroup rhabdomyosarcoma studies III and IV. J Clin Oncol 2003;21:638-645.

43 Thompson CF, Kim BJ, Lai C et al. Sinonasal rhabdomyosarcoma: prognostic factors and treatment outcomes. Int Forum Allergy Rhinol 2013;3:678-683.

44 Wurm J, Constantinidis J, Grabenbauer GG et al. Rhabdomyosarcomas of the nose and paranasal sinuses: treatment results in 15 cases. Otolaryngol Head Neck Surg 2005;133:42-50.

45 Llorente JL, Lopez F, Suarez C et al. Sinonasal carcinoma: clinical, pathological, genetic and therapeutic advances. Nat Rev Clin Oncol 2014;11: 460-472.

46 Mourad WF, Hauerstock D, Shourbaji RA et al. Trimodality management of sinonasal undifferentiated carcinoma and review of the literature. Am J Clin Oncol 2013;36:584-588.

47 Chambers KJ, Lehmann AE, Remenschneider A et al. Incidence and survival patterns of sinonasal undifferentiated carcinoma in the United States. J Neurol Surg B Skull Base 2015;76:94-100.

48 Reiersen DA, Pahilan ME, Devaiah AK. Meta-analysis of treatment outcomes for sinonasal undifferentiated carcinoma. Otolaryngol Head Neck Surg 2012;147: 7-14.

49 Xu CC, Dziegielewski PT, McGaw WT et al. Sinonasal undifferentiated carcinoma (SNUC): the Alberta experience and literature review. J Otolaryngol Head Neck Surg 2013;42:2.

50 Ejaz A, Wenig BM. Sinonasal undifferentiated carcinoma: clinical and pathologic features and a discussion on classification, cellular differentiation, and differential diagnosis. Adv Anat Pathol 2005;12: 134-143.

51 Bell D, Hanna EY. Sinonasal undifferentiated carcinoma: morphological heterogeneity, diagnosis, management and biological markers. Expert Rev Anticancer Ther 2013;13:285-296.

52 Smith SR, Som P, Fahmy A et al. A clinicopathological study of sinonasal neuroendocrine carcinoma and sinonasal undifferentiated carcinoma. Laryngoscope 2000;110:1617-1622.

$53 \mathrm{Su}$ SY, Bell D, Hanna EY. Esthesioneuroblastoma, neuroendocrine carcinoma, and sinonasal undifferentiated carcinoma: differentiation in diagnosis and treatment. Int Arch Otorhinolaryngol 2014;18: S149-S156.

54 Bishop JA, Antonescu CR, Westra WH. SMARCB1 (INI-1)-deficient carcinomas of the sinonasal tract. Am J Surg Pathol 2014;38:1282-1289.

55 Bishop JA. Recently described neoplasms of the sinonasal tract. Semin Diagn Pathol 2016;33:62-70.

56 Chernock RD, Perry A, Pfeifer JD et al. Receptor tyrosine kinases in sinonasal undifferentiated carcinomas - evaluation for EGFR, c-KIT, and HER2/neu expression. Head Neck 2009;31:919-927.

57 Wooff JC, Weinreb I, Perez-Ordonez B et al. Calretinin staining facilitates differentiation of olfactory neuroblastoma from other small round blue cell tumors in the sinonasal tract. Am J Surg Pathol 2011;35: 1786-1793.

58 Singh L, Ranjan R, Arava S et al. Role of p40 and cytokeratin $5 / 6$ in the differential diagnosis of sinonasal undifferentiated carcinoma. Ann Diagn Pathol 2014; 18:261-265.

59 Wadsworth B, Bumpous JM, Martin AW et al. Expression of p16 in sinonasal undifferentiated carci- noma (SNUC) without associated human papillomavirus (HPV). Head Neck Pathol 2011;5:349-354.

60 Gray ST, Herr MW, Sethi RK et al. Treatment outcomes and prognostic factors, including human papillomavirus, for sinonasal undifferentiated carcinoma: a retrospective review. Head Neck 2015;37: 366-374.

61 Cerilli LA, Holst VA, Brandwein MS et al. Sinonasal undifferentiated carcinoma: immunohistochemical profile and lack of EBV association. Am J Surg Pathol 2001;25:156-163.

62 Al-Mamgani A, van RP, Mehilal R et al. Combinedmodality treatment improved outcome in sinonasal undifferentiated carcinoma: single-institutional experience of 21 patients and review of the literature. Eur Arch Otorhinolaryngol 2013;270:293-299.

63 Bossi P, Saba NF, Vermorken JB et al. The role of systemic therapy in the management of sinonasal cancer: a critical review. Cancer Treat Rev 2015;41: 836-843.

64 Rosenthal DI, Barker JL Jr., el-Naggar AK et al. Sinonasal malignancies with neuroendocrine differentiation: patterns of failure according to histologic phenotype. Cancer 2004;101:2567-2573.

65 Yoshida E, Aouad R, Fragoso R et al. Improved clinical outcomes with multi-modality therapy for sinonasal undifferentiated carcinoma of the head and neck. Am J Otolaryngol 2013;34:658-663.

66 Menon S, Pai P, Sengar M et al. Sinonasal malignancies with neuroendocrine differentiation: case series and review of literature. Indian $\mathrm{J}$ Pathol Microbiol 2010;53:28-34.

67 Shah AA, Jeffus SK, Stelow EB. Squamous cell carcinoma variants of the upper aerodigestive tract: a comprehensive review with a focus on genetic alterations. Arch Pathol Lab Med 2014;138:731-744.

68 Stelow EB, French CA. Carcinomas of the upper aerodigestive tract with rearrangement of the nuclear protein of the testis (NUT) gene (NUT midline carcinomas). Adv Anat Pathol 2009;16:92-96.

69 Stelow EB, Bellizzi AM, Taneja K et al. NUT rearrangement in undifferentiated carcinomas of the upper aerodigestive tract. Am J Surg Pathol 2008;32: 828-834.

70 Fang W, French CA, Cameron MJ et al. Clinicopathological significance of NUT rearrangements in poorly differentiated malignant tumors of the upper respiratory tract. Int J Surg Pathol 2013;21:102-110.

71 French CA. The importance of diagnosing NUT midline carcinoma. Head Neck Pathol 2013;7:11-16.

72 French CA. NUT midline carcinoma. Cancer Genet Cytogenet 2010;203:16-20.

73 Bauer DE, Mitchell CM, Strait KM et al. Clinicopathologic features and long-term outcomes of NUT midline carcinoma. Clin Cancer Res 2012;18: 5773-5779.

74 Bishop JA, Westra WH. NUT midline carcinomas of the sinonasal tract. Am J Surg Pathol 2012;36: 1216-1221.

75 Solomon LW, Magliocca KR, Cohen C et al. Retrospective analysis of nuclear protein in testis (NUT) midline carcinoma in the upper aerodigestive tract and mediastinum. Oral Surg Oral Med Oral Pathol Oral Radiol 2015;119:213-220.

76 French CA, Kutok JL, Faquin WC et al. Midline carcinoma of children and young adults with NUT rearrangement. J Clin Oncol 2004;22:4135-4139. 
77 Haack H, Johnson LA, Fry CJ et al. Diagnosis of NUT midline carcinoma using a NUT-specific monoclonal antibody. Am J Surg Pathol 2009;33:984-991.

78 Sun H, McGuire MF, Zhang S et al. NUT midline carcinoma: morphoproteomic characterization with genomic and therapeutic correlates. Ann Clin Lab Sci 2015;45:692-701.

79 Patel TD, Vazquez A, Dubal PM et al. Sinonasal neuroendocrine carcinoma: a population-based analysis of incidence and survival. Int Forum Allergy Rhinol 2015;5:448-453.

80 Perez-Ordonez B, Caruana SM, Huvos AG et al. Small cell neuroendocrine carcinoma of the nasal cavity and paranasal sinuses. Hum Pathol 1998;29: 826-832.

81 Bell D, Hanna EY, Weber RS et al. Neuroendocrine neoplasms of the sinonasal region. Head Neck 2015;38 Suppl 1:E2259-E2266.

82 Laco J, Sieglova K, Vosmikova H et al. The presence of high-risk human papillomavirus (HPV) E6/E7 mRNA transcripts in a subset of sinonasal carcinomas is evidence of involvement of HPV in its etiopathogenesis. Virchows Arch 2015;467:405-415.

83 Mitchell EH, Diaz A, Yilmaz T et al. Multimodality treatment for sinonasal neuroendocrine carcinoma. Head Neck 2012;34:1372-1376.

84 Babin E, Rouleau V, Vedrine PO et al. Small cell neuroendocrine carcinoma of the nasal cavity and paranasal sinuses. J Laryngol Otol 2006;120:289-297.

85 Chai L, Ying HF, Wu TT et al. Clinical features and hypoxic marker expression of primary sinonasal and laryngeal small-cell neuroendocrine carcinoma: a small case series. World J Surg Oncol 2014;12:199.

86 Franchi A, Rocchetta D, Palomba A et al. Primary combined neuroendocrine and squamous cell carcinoma of the maxillary sinus: report of a case with immunohistochemical and molecular characterization. Head Neck Pathol 2015;9:107-113.

87 La RS, Furlan D, Franzi F et al. Mixed exocrineneuroendocrine carcinoma of the nasal cavity: clinico-pathologic and molecular study of a case and review of the literature. Head Neck Pathol 2013;7: 76-84.

88 Chapman-Fredricks J, Jorda M, Gomez-Fernandez C. A limited immunohistochemical panel helps differentiate small cell epithelial malignancies of the sinonasal cavity and nasopharynx. Appl Immunohistochem Mol Morphol 2009;17:207-210.

89 Mills SE. Neuroectodermal neoplasms of the head and neck with emphasis on neuroendocrine carcinomas. Mod Pathol 2002;15:264-278.

90 van der Laan TP, Bij HP, van Hemel BM et al. The importance of multimodality therapy in the treatment of sinonasal neuroendocrine carcinoma. Eur Arch Otorhinolaryngol 2013;270:2565-2568.

91 van den $\mathrm{BH}$, Merks $\mathrm{JH}$. Incidence and grading of cranio-facial osteosarcomas. Int J Oral Maxillofac Surg 2014;43:7-12.

92 Lee RJ, Arshi A, Schwartz HC et al. Characteristics and prognostic factors of osteosarcoma of the jaws: a retrospective cohort study. JAMA Otolaryngol Head Neck Surg 2015;141:470-477.

93 Cheng YS, Wright JM, Walstad WR et al. Osteosarcoma arising in Paget's disease of the mandible. Oral Oncol 2002;38:785-792.

94 Shao Z, He Y, Wang L et al. Computed tomography findings in radiation-induced osteosarcoma of the jaws. Oral Surg Oral Med Oral Pathol Oral Radiol Endod 2010;109:e88-e94.

95 Jeon DG, Koh JS, Cho WH et al. Clinical outcome of low-grade central osteosarcoma and role of CDK4 and MDM2 immunohistochemistry as a diagnostic adjunct. J Orthop Sci 2015;20:529-537.

96 Dujardin F, Binh MB, Bouvier C et al. MDM2 and CDK4 immunohistochemistry is a valuable tool in the differential diagnosis of low-grade osteosarcomas and other primary fibro-osseous lesions of the bone. Mod Pathol 2011;24:624-637.

97 Jasnau S, Meyer U, Potratz J et al. Craniofacial osteosarcoma experience of the cooperative GermanAustrian-Swiss osteosarcoma study group. Oral Oncol 2008;44:286-294.

98 Baumhoer D, Brunner P, Eppenberger-Castori S et al. Osteosarcomas of the jaws differ from their peripheral counterparts and require a distinct treatment approach. Experiences from the DOESAK Registry. Oral Oncol 2014;50:147-153.

99 Chan JKC. Viral related neoplasms of the nasopharynx and sinonasal tract. Mod Pathol (in press).

100 Chuang SS, Lin CN, Li CY. Malignant lymphoma in southern Taiwan according to the revised EuropeanAmerican classification of lymphoid neoplasms. Cancer 2000;89:1586-1592.

101 Aoki R, Karube K, Sugita Y et al. Distribution of malignant lymphoma in Japan: analysis of 2260 cases, 2001-2006. Pathol Int 2008;58:174-182.

102 Laurini JA, Perry AM, Boilesen E et al. Classification of non-Hodgkin lymphoma in Central and South America: a review of 1028 cases. Blood 2012;120: 4795-4801.

103 de Campos-Lima PO, Gavioli R, Zhang QJ et al. HLAA11 epitope loss isolates of Epstein-Barr virus from a highly A11+ population. Science 1993;260:98-100.

104 Jhuang JY, Chang ST, Weng SF et al. Extranodal natural killer/T-cell lymphoma, nasal type in Taiwan: a relatively higher frequency of T-cell lineage and poor survival for extranasal tumors. Hum Pathol 2015;46:313-321.

105 Pongpruttipan T, Sukpanichnant S, Assanasen T et al. Extranodal NK/T-cell lymphoma, nasal type, includes cases of natural killer cell and alphabeta, gammadelta, and alphabeta/gammadelta T-cell origin: a comprehensive clinicopathologic and phenotypic study. Am J Surg Pathol 2012;36:481-499.

106 Suzuki R, Suzumiya J, Yamaguchi M et al. Prognostic factors for mature natural killer (NK) cell neoplasms: aggressive NK cell leukemia and extranodal NK cell lymphoma, nasal type. Ann Oncol 2010;21:1032-1040.

107 Miller DC, Goodman ML, Pilch BZ et al. Mixed olfactory neuroblastoma and carcinoma. A report of two cases. Cancer 1984;54:2019-2028.

108 D'Aguillo C, Soni RS, Gordhan C et al. Sinonasal extramedullary plasmacytoma: a systematic review of 175 patients. Int Forum Allergy Rhinol 2014;4: 156-163.

109 Susnerwala SS, Shanks JH, Banerjee SS et al. Extramedullary plasmacytoma of the head and neck region: clinicopathological correlation in 25 cases. Br J Cancer 1997;75:921-927.

$110 \mathrm{Au}$ WY, Weisenburger DD, Intragumtornchai T et al. Clinical differences between nasal and extranasal natural killer/T-cell lymphoma: a study of 136 cases from the International Peripheral T-Cell Lymphoma Project. Blood 2009;113:3931-3937. 
111 Li S, Feng X, Li T et al. Extranodal NK/T-cell lymphoma, nasal type: a report of 73 cases at MD Anderson Cancer Center. Am J Surg Pathol 2013;37:14-23.

112 Chuang SS. In situ hybridisation for Epstein-Barr virus as a differential diagnostic tool for $\mathrm{T}$ - and natural killer/T-cell lymphomas in non-immunocompromised patients. Pathology 2014;46:581-591.

113 Swerdlow SH, Jaffe ES, Brousset P et al. Cytotoxic T-cell and NK-cell lymphomas: current questions and controversies. Am J Surg Pathol 2014;38:e60-e71.

114 Chuang SS, Ko YH. Cutaneous nonmycotic T- and natural killer/T-cell lymphomas: diagnostic challenges and dilemmas. J Am Acad Dermatol 2014;70:724-735.

115 Jaffe ES, Nicolae A, Pittaluga S. Peripheral T-cell and NK-cell lymphomas in the WHO classification: pearls and pitfalls. Mod Pathol 2013;26 Suppl 1:S71-S87.

116 Boll M, Parkins E, O'Connor SJ et al. Extramedullary plasmacytoma are characterized by a 'myeloma-like' immunophenotype and genotype and occult bone marrow involvement. Br J Haematol 2010;151: $525-527$.

117 Lee J, Suh C, Park YH et al. Extranodal natural killer T-cell lymphoma, nasal-type: a prognostic model from a retrospective multicenter study. J Clin Oncol 2006;24:612-618.

118 Tse E, Kwong YL. How I treat NK/T-cell lymphomas. Blood 2013;121:4997-5005.

119 Khong PL, Huang B, Lee EY et al. Midtreatment (1)(8) F-FDG PET/CT scan for early response assessment of SMILE therapy in natural killer/T-cell lymphoma: a prospective study from a single center. J Nucl Med 2014;55:911-916.

120 Kwong YL, Kim WS, Lim ST et al. SMILE for natural killer/T-cell lymphoma: analysis of safety and efficacy from the Asia Lymphoma Study Group. Blood 2012;120:2973-2980.

121 Dimopoulos MA, Hamilos G. Solitary bone plasmacytoma and extramedullary plasmacytoma. Curr Treat Options Oncol 2002;3:255-259.

122 Kondo N, Takahashi H, Nii Y et al. Olfactory neuroblastoma: 15 years of experience. Anticancer Res 2012;32:1697-1703.

123 Song CM, Won TB, Lee CH et al. Treatment modalities and outcomes of olfactory neuroblastoma. Laryngoscope 2012;122:2389-2395.

124 Thompson LD. Olfactory neuroblastoma. Head Neck Pathol 2009;3:252-259.

125 Broich G, Pagliari A, Ottaviani F. Esthesioneuroblastoma: a general review of the cases published since the discovery of the tumour in 1924. Anticancer Res 1997;17:2683-2706.

126 Jethanamest D, Morris LG, Sikora AG et al. Esthesioneuroblastoma: a population-based analysis of survival and prognostic factors. Arch Otolaryngol Head Neck Surg 2007;133:276-280.

127 Platek ME, Merzianu M, Mashtare TL et al. Improved survival following surgery and radiation therapy for olfactory neuroblastoma: analysis of the SEER database. Radiat Oncol 2011;6:41.

128 Gabbay U, Leider-Trejo L, Marshak G et al. A case and a series of published cases of esthesioneuroblastoma (ENB) in which long-standing paraneoplastic SIADH had preceded ENB diagnosis. Ear Nose Throat J 2013;92:E6.

129 Mills SE, Frierson HF Jr.. Olfactory neuroblastoma. A clinicopathologic study of 21 cases. Am J Surg Pathol 1985;9:317-327.
130 Bell D, Saade R, Roberts D et al. Prognostic utility of Hyams histological grading and Kadish-Morita staging systems for esthesioneuroblastoma outcomes. Head Neck Pathol 2015;9:51-59.

131 Kadish S, Goodman M, Wang CC. Olfactory neuroblastoma. A clinical analysis of 17 cases. Cancer 1976;37:1571-1576.

132 Kaur G, Kane AJ, Sughrue ME et al. The prognostic implications of Hyam's subtype for patients with Kadish stage C esthesioneuroblastoma. J Clin Neurosci 2013;20:281-286.

133 Hyams VJ, Batsakis JG, Michaels L. Tumors of the Upper Respiratory Tract and Ear2nd ed.Armed Forces Institute of Pathology: Washington, DC, 1988.

134 Saade RE, Hanna EY, Bell D. Prognosis and biology in esthesioneuroblastoma: the emerging role of Hyams grading system. Curr Oncol Rep 2015;17:423.

135 Tajudeen BA, Arshi A, Suh JD et al. Importance of tumor grade in esthesioneuroblastoma survival: a population-based analysis. JAMA Otolaryngol Head Neck Surg 2014;140:1124-1129.

136 Gallagher KK, Spector ME, Pepper JP et al. Esthesioneuroblastoma: updating histologic grading as it relates to prognosis. Ann Otol Rhinol Laryngol 2014; 123:353-358.

137 Van Gompel JJ, Giannini C, Olsen KD et al. Long-term outcome of esthesioneuroblastoma: hyams grade predicts patient survival. J Neurol Surg B Skull Base 2012;73:331-336.

138 Malouf GG, Casiraghi O, Deutsch E et al. Low- and high-grade esthesioneuroblastomas display a distinct natural history and outcome. Eur J Cancer 2013;49: 1324-1334.

139 Bates T, Plessis DD, Polvikoski T et al. Ganglioneuroblastic transformation in olfactory neuroblastoma. Head Neck Pathol 2012;6:150-155.

140 Bishop JA, Thompson LD, Cardesa A et al. Rhabdomyoblastic differentiation in head and neck malignancies other than rhabdomyosarcoma. Head Neck Pathol 2015;9:507-518.

141 Faragalla H, Weinreb I. Olfactory neuroblastoma: a review and update. Adv Anat Pathol 2009;16:322-331.

142 Argani P, Perez-Ordonez B, Xiao H et al. Olfactory neuroblastoma is not related to the Ewing family of tumors: absence of EWS/FLI1 gene fusion and MIC2 expression. Am J Surg Pathol 1998;22:391-398.

143 Bourne TD, Bellizzi AM, Stelow EB et al. p63 Expression in olfactory neuroblastoma and other small cell tumors of the sinonasal tract. Am J Clin Pathol 2008;130:213-218.

144 Kumar S, Perlman E, Pack S et al. Absence of EWS/ FLI1 fusion in olfactory neuroblastomas indicates these tumors do not belong to the Ewing's sarcoma family. Hum Pathol 1999;30:1356-1360.

145 Matayoshi R, Otaki JM. Immunohistochemical detection of olfactory-specific sensory transduction proteins in olfactory neuroblastoma. Neurosci Res 2011;69:258-262.

146 Holbrook EH, Wu E, Curry WT et al. Immunohistochemical characterization of human olfactory tissue. Laryngoscope 2011;121:1687-1701.

147 Allam A, El-Husseiny G, Khafaga Y et al. Ewing's Sarcoma of the Head and Neck: A Retrospective Analysis of 24 Cases. Sarcoma 1999;3:11-15.

148 Windfuhr JP. Primitive neuroectodermal tumor of the head and neck: incidence, diagnosis, and management. Ann Otol Rhinol Laryngol 2004;113:533-543. 
149 Holsinger FC, Hafemeister AC, Hicks MJ et al. Differential diagnosis of pediatric tumors of the nasal cavity and paranasal sinuses: a 45-year multi-institutional review. Ear Nose Throat J 2010;89:534-540.

150 Hafezi S, Seethala RR, Stelow EB et al. Ewing's family of tumors of the sinonasal tract and maxillary bone. Head Neck Pathol 2011;5:8-16.

151 Folpe AL, Goldblum JR, Rubin BP et al. Morphologic and immunophenotypic diversity in Ewing family tumors: a study of 66 genetically confirmed cases. Am J Surg Pathol 2005;29:1025-1033.

152 Bishop JA, Alaggio R, Zhang L et al. Adamantinoma-like Ewing family tumors of the head and neck: a pitfall in the differential diagnosis of basaloid and myoepithelial carcinomas. Am J Surg Pathol 2015;39:1267-1274.

153 Machado I, Mayordomo-Aranda E, Scotlandi K et al. Immunoreactivity using anti-ERG monoclonal antibodies in sarcomas is influenced by clone selection. Pathol Res Pract 2014;210:508-513.

154 Tomlins SA, Palanisamy N, Brenner JC et al. Usefulness of a monoclonal ERG/FLI1 antibody for immunohistochemical discrimination of Ewing family tumors. Am J Clin Pathol 2013;139:771-779.

$155 \mathrm{Gu}$ M, Antonescu CR, Guiter G et al. Cytokeratin immunoreactivity in Ewing's sarcoma: prevalence in 50 cases confirmed by molecular diagnostic studies. Am J Surg Pathol 2000;24:410-416.

156 Italiano A, Sung YS, Zhang L et al. High prevalence of CIC fusion with double-homeobox (DUX4) transcription factors in EWSR1-negative undifferentiated small blue round cell sarcomas. Genes Chromosomes Cancer 2012;51:207-218.

157 Specht K, Sung YS, Zhang L et al. Distinct transcriptional signature and immunoprofile of CIC-DUX4 fusion-positive round cell tumors compared to EWSR1-rearranged Ewing sarcomas: further evidence toward distinct pathologic entities. Genes Chromosomes Cancer 2014;53:622-633.

158 Mertens F, Antonescu CR, Hohenberger $\mathrm{P}$ et al. Translocation-related sarcomas. Semin Oncol 2009; 36:312-323.

159 Thompson LD, Seethala RR, Muller S. Ectopic sphenoid sinus pituitary adenoma (ESSPA) with normal anterior pituitary gland: a clinicopathologic and immunophenotypic study of 32 cases with a comprehensive review of the english literature. Head Neck Pathol 2012;6:75-100.

160 Ozgen T, Oruckaptan HH, Ozcan OE et al. Prolactin secreting pituitary adenomas: analysis of 429 surgically treated patients, effect of adjuvant treatment modalities and review of the literature. Acta Neurochir (Wien ) 1999;141:1287-1294.

161 Ezzat S, Asa SL, Couldwell WT et al. The prevalence of pituitary adenomas: a systematic review. Cancer 2004;101:613-619.

162 Coire CI, Horvath E, Kovacs K et al. Cushing's syndrome from an ectopic pituitary adenoma with peliosis: a histological, immunohistochemical, and ultrastructural study and review of the literature. Endocr Pathol 1997;8:65-74.

163 Yang BT, Chong VF, Wang ZC et al. Sphenoid sinus ectopic pituitary adenomas: CT and MRI findings. Br J Radiol 2010;83:218-224.

164 Lloyd RV, Chandler WF, Kovacs K et al. Ectopic pituitary adenomas with normal anterior pituitary glands. Am J Surg Pathol 1986;10:546-552.

165 Asa SL, Ezzat S. The pathogenesis of pituitary tumors. Annu Rev Pathol 2009;4:97-126.

166 Nikitakis NG, Salama AR, O’Malley BW Jr et al. Malignant peripheral primitive neuroectodermal tumor-peripheral neuroepithelioma of the head and neck: a clinicopathologic study of five cases and review of the literature. Head Neck 2003;25:488-498. 